ANL-7 7-74

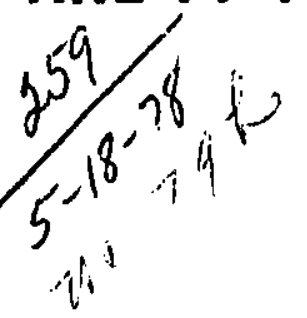

\title{
BILINEAR CYCLIC STRESS-STRAIN ANALYSIS FOR INCOLOY 800
}

\author{
by \\ P. S. Maiya
}

\begin{abstract}
APPLIED TECHNOLOGY
Any further distribution by any holder of this document or of the data therein to third parties representing foreign interests, foreign governments, foreign companies and foreign subsidiaries or foreign divisions of U. S. companies should be coordinated with the Director. Division of Reactor Development and Demonstration, U. S. Department of Energy.
\end{abstract}

\section{ARGONNE NATIONAL LABORATORY, ARGONNE, ILLINOIS

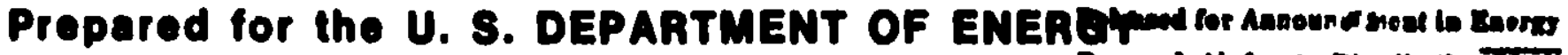 under Contract W-31-109-Eng-38



TABLE OF CONTENTS

$\underline{\text { Page }}$

ABSTRACT .......................

INTRODUCTION. ......................

EXPERIMENTAL MATERIAL AND PROCEDURE. . . . . . . . . 9

BILINEAR CYCLIC STRESS-STRAIN ANALYSIS $\ldots \ldots \ldots \ldots \ldots$

RESULTS AND DISCUSSION $\ldots \ldots \ldots \ldots \ldots \ldots \ldots \ldots \ldots$

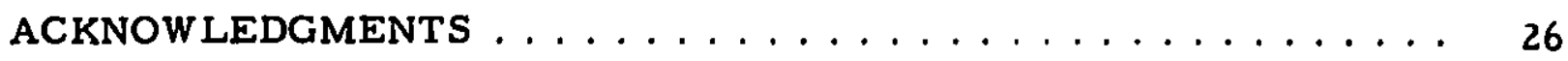

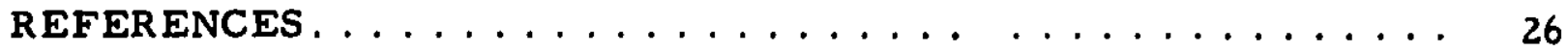




\section{LIST OF FIGURES}

No.

Title

Page

1. Microstructure of Solution-annealed Incoloy $800 \ldots \ldots \ldots$

2. Bilinear Representation of Monotonic, Initial-loading StressStrain Curve........................ 11

3. Bilinear Representation of Initial and Tenth-cycle Stress-Strain Curves. . . ..................... 11

4. Schematic Representation of a Hysteresis Loop Used in Bilinear Cyclic Stress-Strain Analysis.

5. Variation of $E_{m}$ with $\varepsilon_{\max }$ at Room Temperature . . . . . . . 13

6. Variation of $\mathrm{C}$ with $\varepsilon_{\max }$ at Room Temperature . . . . . . . . 13

7. Variations of $E_{m}$ and $C$ with $\varepsilon_{\max }$ at $538^{\circ} \mathrm{C}\left(1000^{\circ} \mathrm{F}\right) \ldots \ldots 14$

8. Variation of $\mathrm{C}$ with $\varepsilon_{\max }$ at $427^{\circ} \mathrm{C}\left(800^{\circ} \mathrm{F}\right)$ ar $593^{\circ} \mathrm{C}\left(1100^{\circ} \mathrm{F}\right) \ldots 14$

9. Variation of $E_{m}$ with $\varepsilon_{\max }$ at $427^{\circ} \mathrm{C}\left(800^{\circ} \mathrm{F}\right)$ and $593^{\circ} \mathrm{C}\left(1100^{\circ} \mathrm{F}\right) \ldots 14$

10. Bilinear Yield Stress as a Function of $\epsilon_{\max }$ at Room

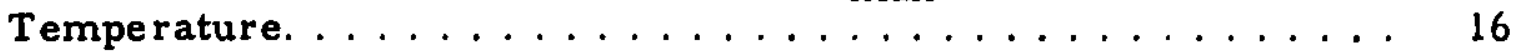

11. Variation of Parameter $k$ with $\varepsilon_{\max }$ at Room Temperature . . . 16

12. Bilinear Yield Stress as a Function of $e_{\max }$ at $427^{\circ} \mathrm{C}\left(800^{\circ} \mathrm{F}\right) \ldots \ldots 16$

13. Variation of Parameter $k$ with $e_{\max }$ at $427^{\circ} \mathrm{C}\left(800^{\circ} \mathrm{F}\right) \ldots \ldots 16$

14. Bilinear Yield Stress as a Function of $\varepsilon_{\max }$ at $538^{\circ} \mathrm{C}\left(1000^{\circ} \mathrm{F}\right) \ldots 16$

15. Variation of Parameter $k$ with $\varepsilon_{\max }$ at $538^{\circ} \mathrm{C}\left(1000^{\circ} \mathrm{F}\right) \ldots \ldots 16$

16. Bilinear Yield Stress as a Function of $e_{\max }$ at $593^{\circ} \mathrm{C}\left(1100^{\circ} \mathrm{F}\right) \ldots 17$

17. Variation of Parameter $k$ with $e_{\max }$ at $593^{\circ} \mathrm{C}\left(1100^{\circ} \mathrm{F}\right) \ldots \ldots 17$

18. Variation of $\mathrm{C}$ with Temperature . . . . . . . . . . 17

19. Variation of $\mathbf{E}_{\mathbf{m}}$ with Temperature . . . . . . . . . . 17

20. Variation of $\sigma_{0}$ with Temperature . . . . . . . . . 17

21. Variation of $\sigma_{1}$ with Temperature $\ldots \ldots \ldots \ldots \ldots$

22. Variation of $\sigma_{2}$ with Temperature $\ldots \ldots \ldots \ldots 18$

23. Variation of $\sigma_{8}$ with Temperature . . . . . . . . . . 18

24. Variation of Bilinear Yield Stress Range with Accumulated Plastic Strain at Room Temperature. . . . . . . . . . . . 22

25. Variation of Bilinear Yield Stres a Range with Accumulated Plastic Strain at $427^{\circ} \mathrm{C}\left(800^{\circ} \mathrm{F}\right) \ldots \ldots \ldots \ldots \ldots \ldots$ 


\section{LIOTT OF FIGURES}

No.

$\underline{\text { Title }}$

$\underline{\text { Page }}$

26. Variation of Bilinear Yield Stress Range with Accumulated Plastic Strain at $538^{\circ} \mathrm{C}\left(1000^{\circ} \mathrm{F}\right) \ldots \ldots \ldots 23$

27. Variation of Bilinear Yield Stress Range with Accumulated Plastic Strain at $593^{\circ} \mathrm{C}\left(1100^{\circ} \mathrm{F}\right) \ldots \ldots \ldots 23$

28. Fit of Bilinear Cyclic Hardening Parameters to Modified Voce-type Equation at $427^{\circ} \mathrm{C}\left(800^{\circ} \mathrm{F}\right) \ldots \ldots \ldots \ldots \ldots$

29. Fit of Bilinear Cyclic Hardening Parameters to Modified Voce-type Equation at $538^{\circ} \mathrm{C}\left(1000^{\circ} \mathrm{F}\right) \ldots \ldots \ldots \ldots$

30. Fit of Bilinear Cyclic Hardening Parameters to Modified Voce-type Equation at $593^{\circ} \mathrm{C}\left(1100^{\circ} \mathrm{F}\right) \ldots \ldots \ldots \ldots$

31. Dependence of Modified Voce Constant $k_{s v}$ on $k_{\varepsilon} \ldots \ldots . . \ldots 5$

32. Interdependence of Modified Voce Constants $k_{s v}$ and $k_{0 v} \ldots \ldots$. . . . 


\section{LIST OF TABLES}

No.

$\underline{\text { Title }}$

$\underline{\text { Page }}$

I. Chemical Composition of 19.05-mm Plate of Incoloy $800 \ldots \ldots 10$

II. Elastic Constants for Incoloy $800 \ldots \ldots \ldots 11$

III. Bilinear Stress-Strain Parameters $E_{m}$ and $C$ for Incoloy 800. . 13

IV. Bilinear Yield Strengths $\sigma_{0}, \sigma_{1}, \sigma_{25}$ and $\sigma_{s}$ for Incoloy $800 \ldots 15$

V. Bilinear Stress-Strain Parameters $k_{0}, k_{1}, k_{2}$, and $k_{s}$ for

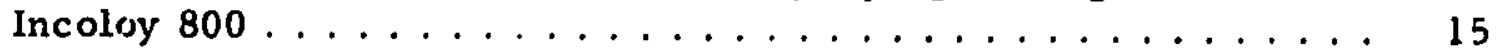

VI. Bilinear Yield Stress, Parameter $k$, and Accumulated Plastic Strain for Incoloy 800 at Room Temperature: $\Delta \varepsilon_{t}=0.4 \%$ and Strain Rate $=8.6 \times 10^{-5} \mathrm{~s}^{-1} \ldots \ldots \ldots \ldots \ldots \ldots \ldots$

VII. Bilinear Yield Stress, Parameter $k$, and Accumulated Plastic Strain for Incoloy 800 at Room Temperature: $\Delta \varepsilon_{t}=0.6 \%$ and Strain Rate $=8.6 \times 10^{-5} \mathrm{~s}^{-1} \ldots \ldots \ldots \ldots \ldots \ldots$

VIII. Bilinear Yield Stress, Parameter $k$, and Accumulated Plastic Strain for Incoloy 800 at Room Temperature: $\Delta \varepsilon_{t}=0.8 \%$ and Strain Rate $=8.6 \times 10^{-5} \mathrm{~s}^{-1} \ldots \ldots \ldots \ldots \ldots \ldots$

IX. Bilinear Yield Stress, Parameter $k$, and Accumulated Plastic Strain for Incoloy 800 at $427^{\circ} \mathrm{C}\left(800^{\circ} \mathrm{F}\right): \Delta e_{t}=0.4 \%$ and Strain Rate $=8.6 \times 10^{-5} \mathrm{~s}^{-1} \ldots \ldots \ldots \ldots \ldots \ldots \ldots \ldots \ldots$

$X$. Bilinear Yield Stress, Parameter $k$, and Accumulated Plastic Strain for Incoloy 800 at $427^{\circ} \mathrm{C}\left(800^{\circ} \mathrm{F}\right): \Delta \epsilon_{t}=0.6 \%$ and Strain Rate $=8.6 \times 10^{-5} \mathrm{~s}^{-1} \ldots \ldots \ldots \ldots \ldots \ldots \ldots \ldots$

XI. Bilinear Yield Stress, Parameter $k$, and Accumulated Plastic Strain for Incoloy 800 at $427^{\circ} \mathrm{C}\left(800^{\circ} \mathrm{F}\right): \Delta e_{t}=0.8 \%$ and Strain Rate $=8.6 \times 10^{-5} \mathrm{~s}^{-1} \ldots \ldots \ldots \ldots \ldots \ldots \ldots$

XII. Bilinear Yield Stress, Parameter $k$, and Accumulated Plastic Strain for Incoloy 800 at $538^{\circ} \mathrm{C}\left(1000^{\circ} \mathrm{F}\right): \Delta \varepsilon_{t}=0.4 \%$ and Strain Rate $=8.6 \times 10^{-5} \mathrm{~s}^{-1} \ldots \ldots \ldots \ldots \ldots \ldots \ldots \ldots \ldots$

XIII. Bilinear Yield Stress, Parameter $k$, and Accumulated Plastic Strain for Incoloy 800 at $538^{\circ} \mathrm{C}\left(1000^{\circ} \mathrm{F}\right): \Delta e_{t}=0.6 \%$ and Strain Rate $=8.6 \times 10^{-5} 8^{-1}$

XIV. Bilinear Yield Stress, Parameter $k$, and Accumulated Plastic Strain for Incoloy 800 at $538^{\circ} \mathrm{C}\left(1000^{\circ} \mathrm{F}\right): \Delta e_{t}=0.8 \%$ and Strain Rate $=8.6 \times 10^{-5} \mathrm{~s}^{-1}$

XV. Bilinear Yield Stress, Parameter $k$, and Accumulated Plastic Strain for Incoloy 800 at $593^{\circ} \mathrm{C}\left(1100^{\circ} \mathrm{F}\right): \Delta e_{t}=0.4 \%$ and Strain Rate $=8.6 \times 10^{-3} \mathrm{~s}^{-1} \ldots \ldots \ldots \ldots \ldots \ldots \ldots \ldots$ 


\section{LIST OF TABLES}

No.

$\underline{\text { Title }}$

Page

XVI. Bilinear Yield Stress, Parameter $k$, and Accumulated Plastic Strain for Incoloy 800 at $593^{\circ} \mathrm{C}\left(1100^{\circ} \mathrm{F}\right): \Delta \varepsilon_{\mathrm{t}}=0.6 \%$ and Strain Rate $=8.6 \times 10^{-5} \mathrm{~s}^{-1} \ldots \ldots \ldots 22$

XVII. Bilinear Yield Stress, Parameter $k$, and Accumulated Plastic Strain for Incoloy 800 at $593^{\circ} \mathrm{C}\left(1100^{\circ} \mathrm{F}\right): \Delta \epsilon_{\mathrm{t}}=0.8 \%$ and Strain Rate $=8.6 \times 10^{-5} \mathrm{~s}^{-1} \ldots \ldots \ldots 22$

XVIII. Empirical Parameters of Modified Voce-type Equations for

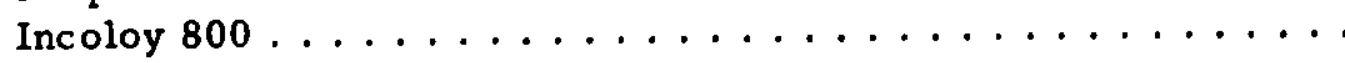





\title{
BILINEAR CYCLIC STRESS-STRAIN ANALYSIS \\ FOR INCOLOY 800
}

\author{
by \\ P. S. Maiya
}

\begin{abstract}
This report describes the bilinear stress-strain analysis under cyclic loading conditions for the alloy Incoloy 800. Although the method for determining the bilinear stress-strain parameters is based on a procedure proposed in the RDT Standard F9-1 for inelastic analysis of Fast Flux Test Facility (FFTF) components, the accuracy and consistency of results have been improved by an arialytical technique, which also resulted in certain simplifications. The bilinear stress-strain parameters of solution-annealed Incoloy 800 (Heat HH7058A) under cyclic loading conditions at a strain rate $\left(\dot{\varepsilon}_{t}\right)$ of $8.6 \mathrm{x}$ $10^{-5} \mathrm{~s}^{-1}$, total strain range $\left(\Delta \sigma_{\mathrm{t}}\right)$ of $0.2-0.8 \%$, and temperatures of room temperature to $593^{\circ} \mathrm{C}\left(1100^{\circ} \mathrm{F}\right)$ have been determined. The dependence of bilinear parameters on temperature and strain is discussed. The cyclic-hardening characteristics based on correlation of yield parameter $k$ with accumulated plastic strain are also presented.
\end{abstract}

\section{INTRODUCTION}

To perform a detailed inelastic analysis of nuclear structural components, the designer must have constitutive equations that consider timeindependent elastic-plastic behavior as well as time-dependent creep behavior. Usually, the elastic-plastic analysis is formulated independent of creep and is based on the von Mises or Tresca yield condition, the classical kinematic hardening rule, and bilinear stress-strain relationships. The present report describes bilinear stress - strain parameters of solution-annealed Incoloy 800 (Heat HH7058A) determined under cyclic loading conditions at a strain rate $\left(\dot{s}_{t}\right)$ of $8.6 \times 10^{-5} \mathrm{~s}^{-1}$, total strain range $\left(\Delta \varepsilon_{t}\right)$ of $0.2-0.8 \%$, and temperatures of room temperature to $593^{\circ} \mathrm{C}\left(1100^{\circ} \mathrm{F}\right)$.

\section{EXPERIMENTAL MATERIAL AND PROCEDURE}

The chemical composition of Incoloy 800 (Heat HH7058A) ie listed in Table I. The hourglass -shape specimens obtained from $0.75-\mathrm{in}$. $(19-\mathrm{mm})$ plate material were solution-annealed at $1135^{\circ} \mathrm{C}\left(2075^{\circ} \mathrm{F}\right)$ for $1 \mathrm{~h}$. The ASTM grain 
size of the annealed material (Fig. 1) is 4.4 , as determined by the intercept method.' The cyclic tests were performed in air in the axial strain-control mode until saturation in stress was achieved. All tests were conducted at a strain rate of $8.6 \times 10^{-5} \mathrm{~s}^{-1}$, total strain ranges of $0.2-0.8 \%$, and at temperatures between room temperature and $593^{\circ} \mathrm{C}\left(1100^{\circ} \mathrm{F}\right)$.

TABLE I. Chemical Composition of 19.05-mm Plate of Incoloy 800 (Heat HH7058A)

\begin{tabular}{lc}
\hline Elements & Analysis, wt \% \\
\hline $\mathrm{C}$ & 0.08 \\
$\mathrm{Mn}$ & 0.78 \\
$\mathrm{~S}$ & 0.002 \\
$\mathrm{Si}$ & 0.46 \\
$\mathrm{Cu}$ & 0.65 \\
$\mathrm{Al}$ & 0.46 \\
$\mathrm{Ti}$ & 0.44 \\
$\mathrm{Fe}$ & 43.46 \\
$\mathrm{Ni}$ & 33.90 \\
$\mathrm{Cr}$ & 19.77 \\
\hline
\end{tabular}

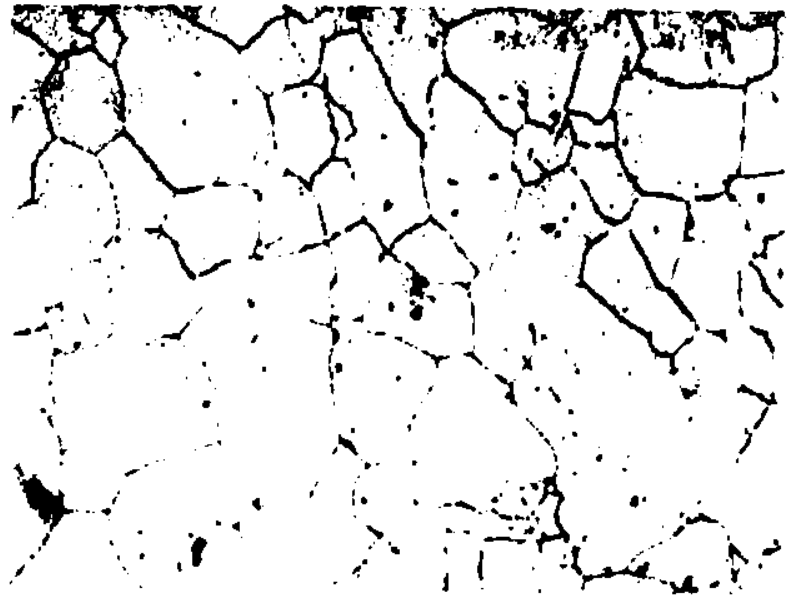

Fig. 1. Microstructure of Solution-annealed Incoloy 800 . Etchant: Glyceregia. ANL Neg. No. 306-77-238.

\section{BILINEAR CYCLIC STRESS-STRAIN ANALYSIS}

The bilinear stress-strain analysis of the hysteresis loops was performed using the procedure outlined in Refs. 2 and 3. Figure 2 shows the procedure for determining bilinear representation of monotonic, initial-loading stress-strain curves. The elastic line (with a slope equal to Young's modulus) is drawn from the origin $O$. The elastic constants for Incoloy 800 were obtained from Ref. 4 and are displayed in Table II. The elastic-plastic segment of the bilinear curve is determined by a straight line connecting the stress at the maximum strain, $\varepsilon_{\max }$, to the stress at strain, $\varepsilon_{\max } / 2$. The bilinear yield stress $\sigma_{0}$. defined by the intersection of the two straight lines OP and PQR, is related to parameter $k_{0}$ by

$$
\sigma_{0}=\sqrt{3 k_{0}} \text {. }
$$

The quantity $C$ is related to the slope $E_{m}$ (Fig. 2) as follows:

$$
C=\frac{2}{3} \frac{E E_{m}}{E-E_{m}} \text {. }
$$

where $E$ is Young's modulus. The parameter $C$ is actually the slope of the elastic-plastic line in terms of deviatoric stress versus plastic strain ep. 
From the value of $(\therefore$ the bilincar parameter $k$ for atis aycle can be retermincel. The bilinear parameters $k_{1}$. $k_{2}$, and $k_{s}$ for the first cycle, tenth cycle, and cycle at saturation, respectively, are determined so that the value of $C$ for any of the hysteresis loops is the same as the value established for the monntonic stress-strain curve. The bilinear parameter $k$ for any cycle from one to ten cycles is also determined assuming the same value of $C$. Furthermore. the intersection of the elastic and elastic-plastic lines are locater so that the s'aded areas above and below the actual curve are equal on both tensile and compressive portions of the cyclic curve (see Fig. 3). Conventionally. the lecation of the ciastic-plastic line is established with the help of planimeter. but this procedure $e^{6.6}$ is tedious and has poor reproducibility. In the present sturly. the intersection of the elastic ancl elastic-plintic lines is determined by using an analytical procedure illustrated in Fif. 4.

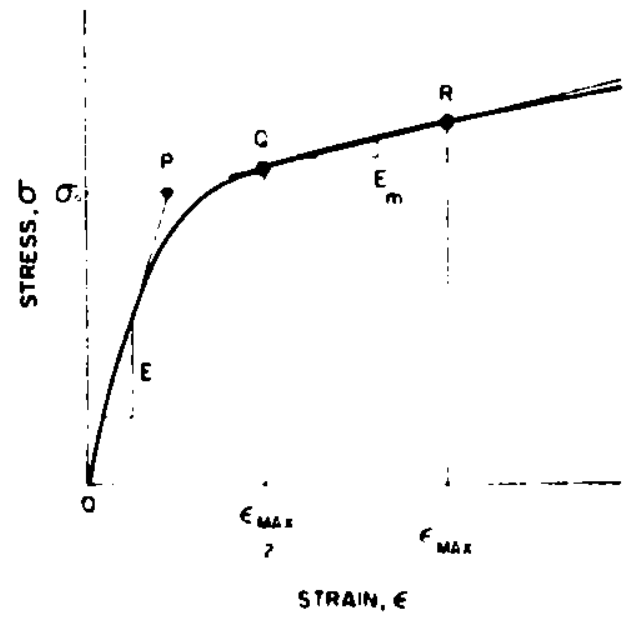

list.:. Bilincar Reprecentaltion of Rono-

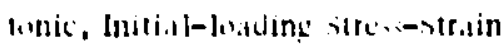

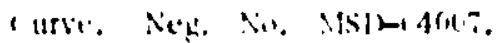

TABLE II. Elastic Constants for Incoloy 800

\begin{tabular}{ccc}
$\begin{array}{c}\text { Temperature, } \\
{ }^{c} \mathrm{C}\left(\mathrm{F}^{\mathrm{F}}\right)\end{array}$ & $\begin{array}{c}\text { Young's Modulus, } \\
10^{3} \mathrm{MPa}\left(10^{3} \mathrm{ksi}\right)\end{array}$ & $\begin{array}{c}\text { Poisson's } \\
\text { Ratio }\end{array}$ \\
\hline $\mathrm{RT}^{\mathrm{a}}$ & $196.50(28.5)$ & 0.339 \\
$427(800)$ & $169.61(24.6)$ & 0.363 \\
$538(1000)$ & $162.03(23.5)$ & 0.367 \\
$593(1100)$ & $157.69(22.9)$ & 0.372 \\
\hline
\end{tabular}

${ }^{a}$ Rooin Temperature.

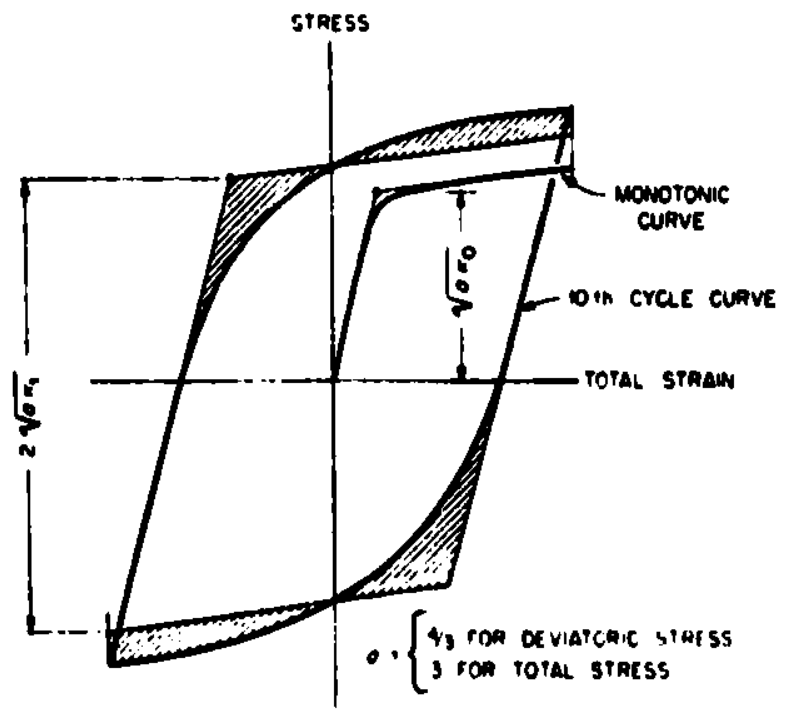

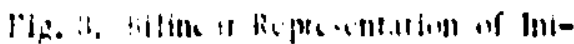

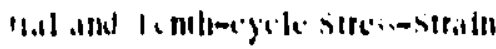

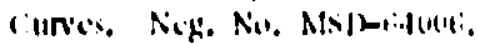

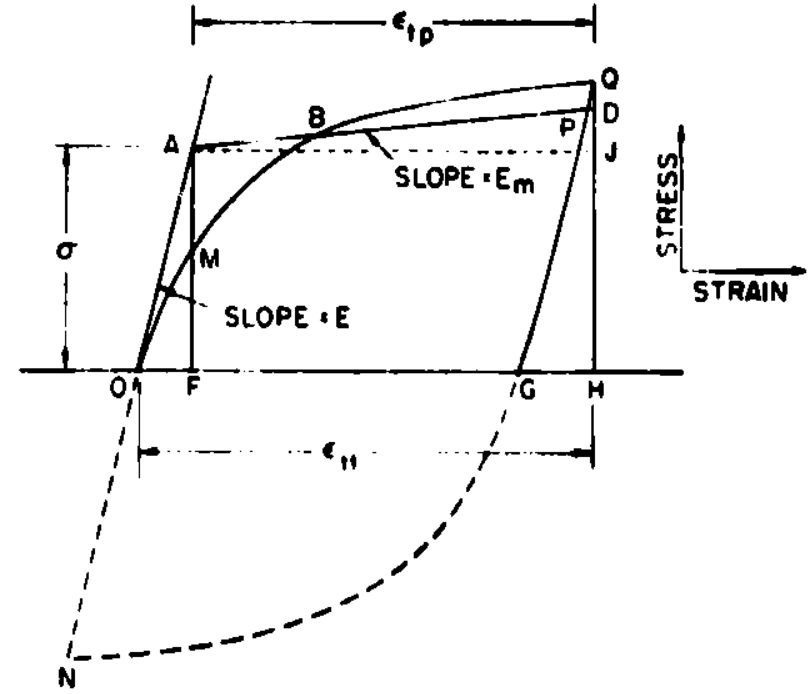

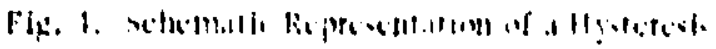

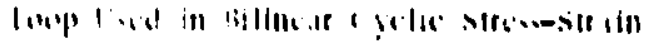
Ans!ṣ. ANt. Seg. No, :101:-77-2.17 Rov. 1. 
Consider the upper half OBQG of a closed hysteresis loop NOBQGN. For determining the bilinear stress parameter, it is required to draw a line $A B P D$ (see Fig. 4) with a slope equal to $E_{m}$ so that the area OABO is equal to area $B Q D B$. This is accomplished by equating area OAPDHO to area OBQHO. With reference to Fig. 4, defining $A F=\sigma, \varepsilon_{t p}=\varepsilon_{t t}-\sigma / E$, and $D J=\varepsilon_{t p} E_{m}$ and designating the area OBQHO by $A_{t}$, we have

$$
A_{t}=\text { area OAPDHO }=\sigma^{2} / 2 \mathrm{E}+\frac{2 \sigma+\varepsilon_{\mathrm{tp}} E_{m}}{2} \epsilon_{\mathrm{tp}} .
$$

Substituling $\left(\varepsilon_{t t}-\sigma / E\right)$ for $\varepsilon_{\ell p}$ and expanding Eq. 3, we obtain the following quadratic equation in $\sigma$ :

$$
\sigma^{2}\left(E_{m}-E\right)+2 \sigma\left(E^{2} \epsilon_{t t}-\varepsilon_{t t} E E_{m}\right)+E_{m} \varepsilon_{t t}^{2} E^{2}-2 A_{t} E^{2}=0 .
$$

The solutions of the above quadratic equation can be simplified and are represented by

$$
\sigma=\varepsilon_{\mathrm{tt}} E \pm \varepsilon_{\mathrm{tt}} \mathrm{E}\left\{1-\left\{\left(2 \mathrm{~A}_{\mathrm{t}} / \epsilon_{\mathrm{tt}}^{2}\right)-E_{m}\right\} /\left(E-E_{m}\right)\right\}^{1 / 2}
$$

For the problem under consideration, it can be easily shown that the only physically acceptable solution is

$$
\sigma=\varepsilon_{t t} E-\varepsilon_{t t} E\left\{1-\left[\left(2 A_{t} / \varepsilon_{t t}^{2}\right)-E_{m}\right] /\left(E-E_{m}\right)\right\}^{1 / 2} .
$$

For calculating $\sigma$ from Eq. 6 , the area $A_{t}$ (area $O B Q H O$ ) is computed by means of numerical-integration procedures. From the symmetry of the hysteresis loop.* the bilinear yield stress for the $i$ th loop $\sigma_{i}$ is given by**

$$
\sigma_{\mathbf{i}}=2 \sigma+\varepsilon_{\mathrm{tp}} \mathrm{E}_{\mathbf{m}}
$$

The bilinear yield stress $\sigma_{i}$ and the parameter $k_{i}$ are related by

$$
k_{i}=\frac{\sigma_{i}^{2}}{12}(i=1-10 \text { and the saturation cycles }) \text {. }
$$

Thus,

$$
k_{B}=\frac{\sigma_{B}^{2}}{12}
$$

*The analysis can also be applled to unsymmetrical loops.

Hol has the same meaning os $\Delta \sigma$ used in Ref. 2. In comparing $\sigma_{0}$ wlth $\sigma_{1}$. nuic that $\sigma_{\text {f }}$ shuuld be divilded hy 2. which ts not done in the present report. However, there is no such Inensistency in tile definitlon of $k_{0}$ and $k_{1}$. 
Table III lists the values for $C$ and $E_{m}$ at strains emax between 0.1 and $0.4 \%\left(\varepsilon_{\max }=\Delta \varepsilon_{t} / 2\right)$ and different temperatures. Figures $5-9$ show the variation of $C$ and $E_{m}$ with $\epsilon_{\max }$ at temperatures from room temperature to $593^{\circ} \mathrm{C}\left(1100^{\circ} \mathrm{F}\right)$. Both $\mathrm{C}$ and $\mathrm{E}_{\mathrm{m}}$ decrease markedly at $\epsilon_{\mathrm{m}} \mathrm{x}$ between 0.1 and $0.2 \%$, beyond which the parameters are approximately independent of strain. (The apparent variation in $C$ and $E_{m}$ at $\epsilon_{\max }$ between 0.1 and $0.2 \%$ does not reflect the true material behavior, but results from the recommended procedure outlined in Refs. 2 and 3.)

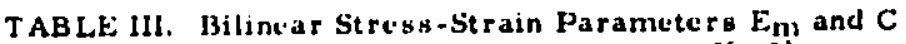
tor incoloy 800 . Strain rate $=8.6 \times 10^{-5} \mathrm{~s}$.

\begin{tabular}{|c|c|c|c|}
\hline $\begin{array}{l}\text { Specimen } \\
\text { Number }\end{array}$ & $\cos _{0}$ & $10^{\prime} \operatorname{MPa}^{\mathrm{E}}\left(10^{\prime} \mathrm{ksi}\right)$ & $\frac{\mathrm{C}}{10^{3} \mathrm{MPa}\left(10^{3} \mathrm{ksi}\right)}$ \\
\hline \multicolumn{4}{|c|}{ Ronm remperature } \\
\hline 1110 & 0.1 & $110.39(16.01)$ & $167.94(24.36)$ \\
\hline 1122 & 0.2 & $15.90(2.31)$ & $11.53(1.67)$ \\
\hline H23 & 0.3 & $6.36(0.922)$ & $4.38(0.035)$ \\
\hline$H<0$ & 0.4 & $6.22(0.902)$ & $+.26(0.621)$ \\
\hline \multicolumn{4}{|c|}{$+27 \mathrm{C}$} \\
\hline$H 5$ & 0.1 & $41.77 \quad(6.06)$ & $36.95 \quad(5.36)$ \\
\hline 116 & 0.2 & $4.043(0.673)$ & $3.183(0.462)$ \\
\hline HII & 0.3 & 3. $775(0.548)$ & $2.57+(0.373)$ \\
\hline H1L & 0.4 & $3.173(0.46)$ & $\therefore 156(0.313)$ \\
\hline \multicolumn{4}{|c|}{$538 \mathrm{C}$} \\
\hline 116 & 0.1 & $30.80 \quad(4.468)$ & $25.357(3.078)$ \\
\hline 1118 & 0.2 & $4 .+72(0.649)$ & $3.060(0.4+5)$ \\
\hline $\mathrm{H4}$ & $0<$ & $9.557(1.386)$ & $6.771(0.982)$ \\
\hline $\mathrm{HI}+$ & 0.3 & $3.624(0.526)$ & $2.472(0.358)$ \\
\hline 1113 & 0.4 & $3.223(0.467)$ & $2192(0.3(8)$ \\
\hline \multicolumn{4}{|c|}{$543 \mathrm{C}$} \\
\hline H24 & 0.1 & $31.52(4.57)$ & $26 . .26(3.81)$ \\
\hline$H$ & 0.1 & $35.79(5.19)$ & $30.8+(4.47)$ \\
\hline H8 & 0.1 & $34.48(5.0)$ & $24.4 \quad(4.26)$ \\
\hline H9 & 0.2 & $11.5 \quad(1.67)$ & $8.27(1.20)$ \\
\hline HL & 0.3 & $2.86(0.415)$ & $1.94(0.282)$ \\
\hline H3 & 0.4 & $2.16(0.313)$ & $1.46(0.211)$ \\
\hline
\end{tabular}

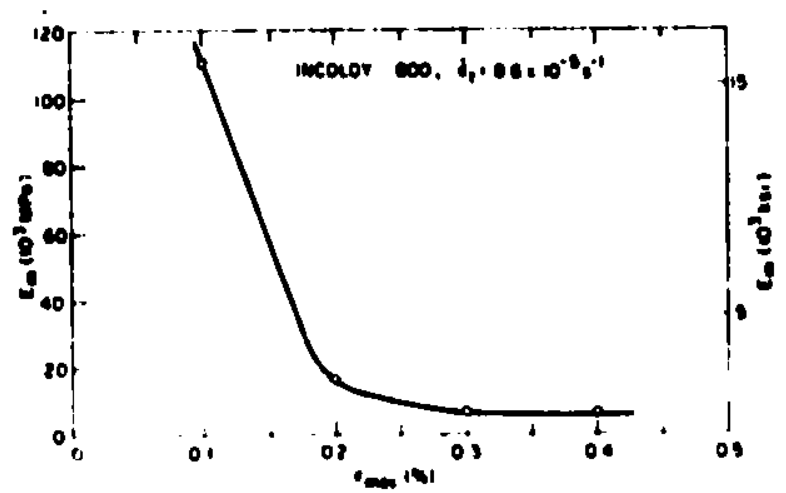

Fig. is. Variation of $\mathrm{E}_{\mathrm{m}}$ with emax dt Roon Temperature. ANI. Neg. No. 3015-77-231.

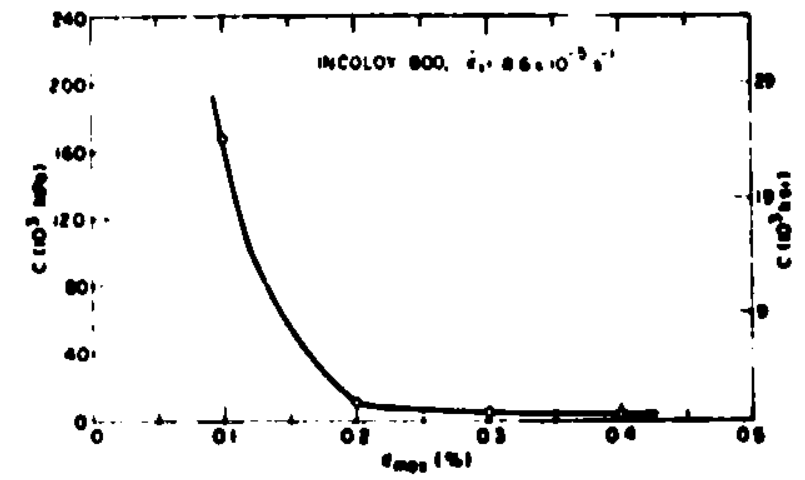

Fig. (i. Variation of $1:$ with emax at Rexum Trmuperature. ANL. Ney. No. 30i-77-2:ss. 


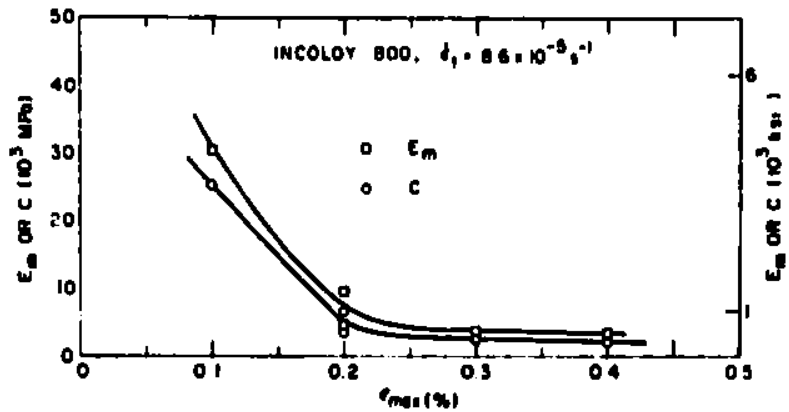

Fig. 7. Varlations of $\mathrm{Em}$ and $\mathrm{C}$, with $8 \mathrm{max}$ at $538^{\circ} \mathrm{r}$ (1000'F). ANl. Neg. No. 306-77-233.

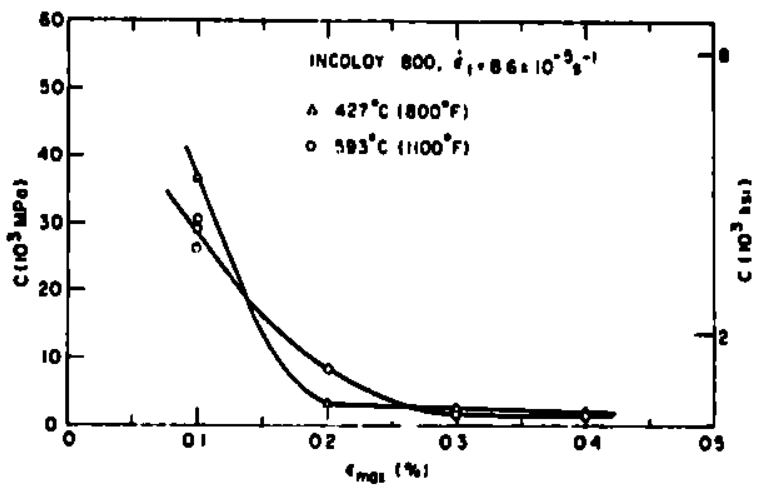

Fig. 8. Variation of $\mathrm{C}$ with $8 \mathrm{max}$ at $427^{\circ} \mathrm{C} \cdot\left(800^{\circ} \mathrm{F}\right)$ and $593^{\circ} \mathrm{C}:\left(1100^{\circ} \mathrm{F}\right)$. Neg. No. MSD-64004.

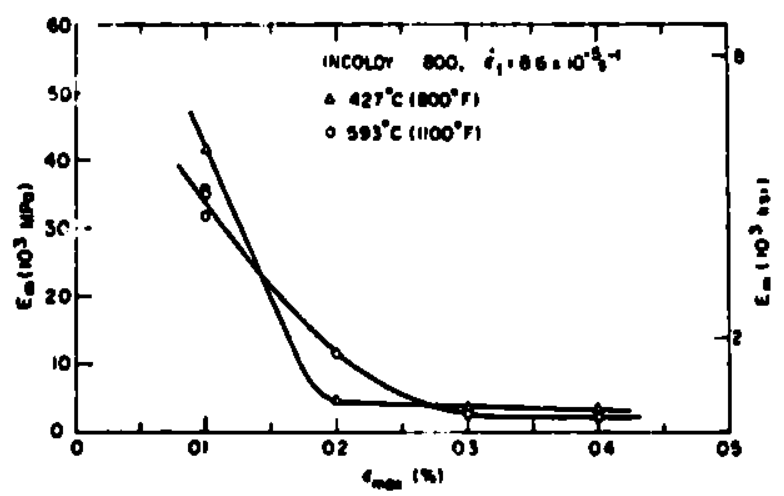

Fig. 9

Vartation of En with $\varepsilon_{\max }$ at $427^{\circ} \mathrm{C}$. $\left(800^{\circ} \mathrm{F}\right)$ and $593^{\circ} \mathrm{C} .\left(1100^{\circ} \mathrm{F}\right)$. Neg. No. MSD-64005.

Tables IV and V list the values of bilinear yield strengths $\sigma_{0}, \sigma_{1}, \sigma_{2}$. and $\sigma_{8}$ and the corresponding $k$ parameters at $e_{\max }$ between 0.1 and $0.4 \%$ for different temperatures. Figures 10-17 describe the variation of both yield stress and the parameter $k$ for the monotonic stress-strain curve, first cycle. tenth cycle, and the saturated hysteresis loop with $\epsilon_{\max }$. The parameter $8 \mathrm{k}_{\mathrm{B}}$ and $\sigma_{B}$ for the saturated hysteresis loop cannot be determined at $\varepsilon_{\max }=$ $0.1 \%$ because the material has approximately elastic behavior in the cyclically hardened state near stress saturation.

Figures 18 and 19 show the variation of parameters $C$ and $E_{m}$ with temperature at differant maximum strains ( 6 max). In the range of maximum strain levels from 0.2 to $0.4 \%$, the bilinear parameters $\mathrm{C}$ and $\mathrm{E}_{\mathrm{m}}$ exhibit a weak dependence on temperature. At ${ }_{\max }=0.1 \%, \mathrm{C}$ and $\mathrm{E}_{\mathrm{m}}$ have aignificantly higher values than those determined at higher temperature. Figures 2023 show the dependence of bilinear yield strengths $\sigma_{0}, \sigma_{1}, \sigma_{2}$ and $\sigma_{8}$ on temperature. At $427-593^{\circ} \mathrm{C}$, the bilinear yield atresses $\sigma_{0}$ and $\sigma_{1}$ are approximately independent of temperature at $\max$ between 0.1 and $0.4 \%$. However, the bilinear yield atrese determined for the 10 th cycle, $\sigma_{2}$, varies with temperature and strain in an anomaluus but consistent manner, which may be attributed to aging offects associated with elevated temperature and cycling. 
TABLE IV. Bilinear Yield Strengths $c_{0}, \sigma_{1}, \sigma_{2}$, and $\sigma_{g}$ for Incoloy 800 . Strain rate $=8.6 \times 10^{-5} \mathrm{~g}^{-1}$.

\begin{tabular}{|c|c|c|c|c|c|}
\hline $\begin{array}{l}\text { Spectmen } \\
\text { Number }\end{array}$ & $\max _{\%}$ & $\operatorname{MPa}_{\mathrm{a}}^{\sigma_{0}}(k \otimes i)$ & $\operatorname{MPa}^{\sigma_{1}}(k a i)$ & $\operatorname{MPa}^{\sigma_{2}}\left(k_{B i}\right)$ & $\operatorname{MPa}_{\mathrm{a}}^{\sigma_{\mathrm{B}}}(\mathrm{ksi})$ \\
\hline \multicolumn{6}{|c|}{ Room Temperature } \\
\hline $\begin{array}{l}\mathrm{H} 10 \\
\mathrm{H} 22 \\
\mathrm{H} 23 \\
\mathrm{H} 20\end{array}$ & $\begin{array}{l}0.1 \\
0.2 \\
0.3 \\
0.4\end{array}$ & $\begin{array}{l}125.86(18.25) \\
164.58(23.87) \\
187.28(27.16) \\
181.44(26.32)\end{array}$ & $\begin{array}{l}278.79(40.43) \\
293.86(42.62) \\
303.91(44.08) \\
347.47(50.40)\end{array}$ & $\begin{array}{l}295.14(42.81) \\
327.73(47.53) \\
357.49(51.85) \\
419.02(60.07)\end{array}$ & $\begin{array}{l}344.92(50.03) \\
422.77(61.32) \\
469.58(68.11)\end{array}$ \\
\hline \multicolumn{6}{|c|}{$427^{\circ} \mathrm{C}$} \\
\hline $\begin{array}{l}\text { H5 } \\
\text { H6 } \\
\text { H11 } \\
\text { H12 }\end{array}$ & $\begin{array}{l}0.1 \\
0.2 \\
0.3 \\
0.4\end{array}$ & $\begin{array}{r}84.51(12.26) \\
101.50(14.72) \\
108.66(15.76) \\
105.34(15.28)\end{array}$ & $\begin{array}{l}160.25(23.24) \\
190.96(27.70) \\
191.66(27.80) \\
212.43(30.81)\end{array}$ & $\begin{array}{l}204.80(29.70) \\
239.59(34.75) \\
269.79(39.13) \\
309.76(44.93)\end{array}$ & $\begin{array}{l}543.51(78.83) \\
562.97(81.65) \\
590.87(85.70)\end{array}$ \\
\hline \multicolumn{6}{|c|}{$\underline{538^{\circ} \mathrm{C}}$} \\
\hline $\begin{array}{l}\mathrm{H} 16 \\
\mathrm{H} 18 \\
\mathrm{H4} \\
\mathrm{H} 14 \\
\mathrm{H} 13\end{array}$ & $\begin{array}{l}0.1 \\
0.2 \\
0.2 \\
0.3 \\
0.4\end{array}$ & $\begin{array}{r}76.87(11.15) \\
104.91(15.22) \\
113.77(16.50) \\
91.77(13.31) \\
94.30(13.68)\end{array}$ & $\begin{array}{l}167.52(24.30) \\
159.37(23.11) \\
197.84(28.69) \\
201.12(29.17) \\
217.06(31.48)\end{array}$ & $\begin{array}{l}172.53(25.02) \\
246.70(35.81) \\
253.85(36.82) \\
313.48(45.47) \\
362.18(52.53)\end{array}$ & $\begin{array}{c} \\
605.87(87.87) \\
546.33(79.24) \\
602.00(87.31)\end{array}$ \\
\hline \multicolumn{6}{|c|}{$\underline{593^{\circ} \mathrm{C}}$} \\
\hline $\begin{array}{l}\mathrm{H} 24 \\
\mathrm{H} 1 \\
\mathrm{H} 8 \\
\mathrm{H} 9 \\
\mathrm{H} 2 \\
\mathrm{H} 3\end{array}$ & $\begin{array}{l}0.1 \\
0.1 \\
0.1 \\
0.2 \\
0.3 \\
0.4\end{array}$ & $\begin{array}{l}80.28(11.64) \\
79.07(11.47) \\
83.70(12.1 .4) \\
86.56(12.55) \\
97.35(14.12) \\
96.51(14.0)\end{array}$ & $\begin{array}{l}169.79(24.62) \\
169.84(24.63) \\
170.82(24.77) \\
185.06(26.84) \\
195.28(28.32) \\
210.26(30.50)\end{array}$ & $\begin{array}{l}184.94(26.82) \\
187.46(27.19) \\
182.69(26.50) \\
243.09(35.26) \\
295.80(42.90) \\
401.40(58.22)\end{array}$ & $\begin{array}{c}\dot{ } \\
479.79(69.59) \\
528.96(76.72) \\
560.46(81.29)\end{array}$ \\
\hline
\end{tabular}

TABLE V. Bilinear Strese-Strain Parameters $k_{0}, k_{1}, k_{2}$, and $k_{6}$ tor Incoloy 800. Strain rate $=8.6 \times 10^{-4} .1$.

\begin{tabular}{|c|c|c|c|c|c|}
\hline $\begin{array}{l}\text { Specimen } \\
\text { Number }\end{array}$ & $\max _{\%}$ & $\operatorname{MPa}^{k_{0}}\left(k \mathrm{ll}^{2}\right)$ & $M P_{1}^{2}\left(k=I^{2}\right)$ & $\operatorname{MPa}_{a^{2}}^{k_{2}}\left(k=l^{2}\right)$ & $\operatorname{MPa}^{2}\left(k \mathrm{si}^{2}\right)$ \\
\hline \multicolumn{6}{|c|}{ Room Temperature } \\
\hline $\begin{array}{l}1110 \\
1122 \\
1123 \\
1120\end{array}$ & $\begin{array}{l}0.1 \\
0.2 \\
0.3 \\
0.4\end{array}$ & $\begin{array}{r}5280(111) \\
9029(190) \\
11691(246) \\
10973(231)\end{array}$ & $\begin{array}{r}6477(136) \\
7196(151) \\
7677(162) \\
10061(212)\end{array}$ & $\begin{array}{r}7259(153) \\
8950(188) \\
10650(224) \\
14631(308)\end{array}$ & $\begin{array}{r}9914(209) \\
14895(313) \\
18375(387)\end{array}$ \\
\hline \multicolumn{6}{|c|}{ $\pm 27^{\circ} \mathrm{C}$} \\
\hline $\begin{array}{l}H 5 \\
H 6 \\
H 11 \\
H I 2\end{array}$ & $\begin{array}{l}0.1 \\
0.2 \\
0.3 \\
0.4\end{array}$ & $\begin{array}{l}2381(50.1) \\
3434(72.2) \\
3936(82.8) \\
3699(77.8)\end{array}$ & $\begin{array}{l}2140(45.0) \\
3034(63.9) \\
3061(64.4) \\
3760(79.1)\end{array}$ & $\begin{array}{l}3495(73.5 ! \\
4784(100.6) \\
6065(127.6) \\
7996(168.2)\end{array}$ & $\begin{array}{l}24617(517.8) \\
26+11(555.6) \\
29094(612.0)\end{array}$ \\
\hline \multicolumn{6}{|c|}{$538^{\circ} \mathrm{C}$} \\
\hline $\begin{array}{l}\text { H16 } \\
1118 \\
H 4 \\
114 \\
1113\end{array}$ & $\begin{array}{l}0.1 \\
0.2 \\
0.2 \\
0.3 \\
0.4\end{array}$ & $\begin{array}{l}1970(41.4) \\
3668(77.2) \\
4314(90.8) \\
2807(59.1) \\
2964(62.4)\end{array}$ & $\begin{array}{lll}2 & 338 & (49.2) \\
2 & 117(44.5) \\
3 & 262(68.6) \\
3 & 371(70.9) \\
3 & 926(82.6)\end{array}$ & $\begin{array}{c}2480(52.2) \\
5040(106.9) \\
5370(113.0) \\
8189(173.5) \\
10931(229.9)\end{array}$ & $\begin{array}{c}= \\
30589(643.5) \\
2487 ;(523.2) \\
30200(635.3)\end{array}$ \\
\hline \multicolumn{6}{|c|}{$593^{\circ} \mathrm{C}$} \\
\hline $\begin{array}{l}1124 \\
111 \\
118 \\
119 \\
112 \\
113\end{array}$ & $\begin{array}{l}0.1 \\
0.1 \\
0.1 \\
0.2 \\
0.3 \\
0.4\end{array}$ & $\begin{array}{ll}2 & 148(45.2) \\
2 & 084(43.8) \\
2 & 335(49.1) \\
2 & 498(52.5) \\
3 & 150(66.5) \\
3 & 104(65.3)\end{array}$ & $\begin{array}{l}2402(50.5) \\
2404(50.6) \\
2431(51.1) \\
2854(60.0) \\
3178(66.8) \\
3684(77.5)\end{array}$ & $\begin{array}{l}2450(60.0) \\
2929(61.6) \\
2781(58.5) \\
4924(103.6) \\
7292(153.4) \\
13426(282.4)\end{array}$ & 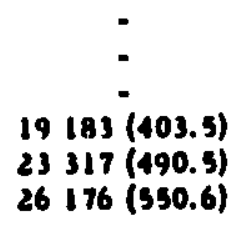 \\
\hline
\end{tabular}




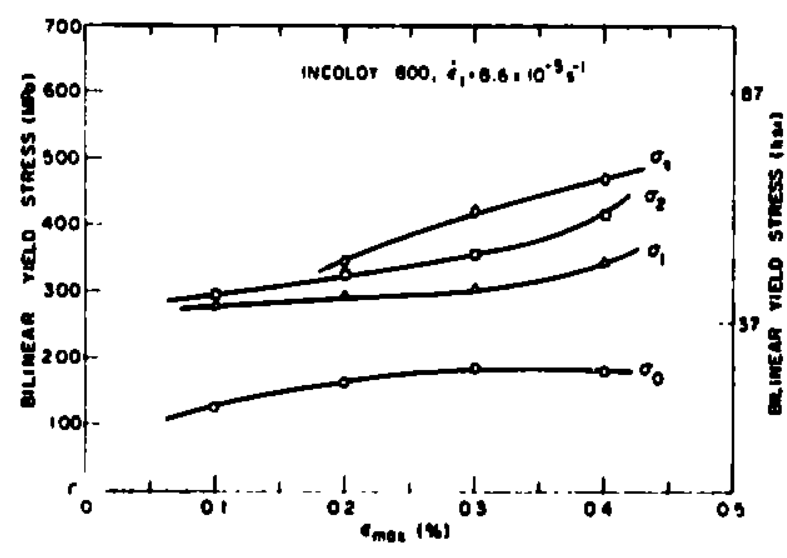

Fig. 10. Bllinear Yleld Stress as a Function of emax at Room Temperature. ANL Neg. No. 306-77-230.

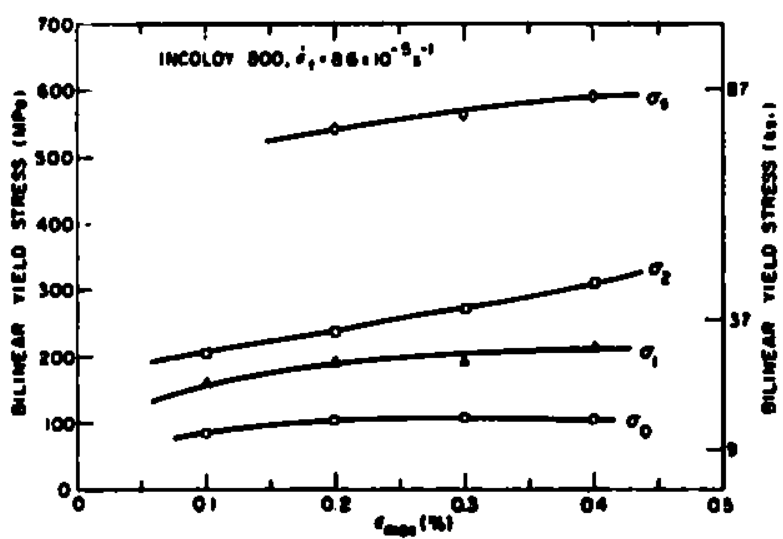

Fig. 12. Bllineat Yleld Stress as a Function of emax at $427^{\circ} \mathrm{C}$ ( $\left(800^{\circ} \mathrm{F}\right)$. ANL Neg. No. 306-77-216.

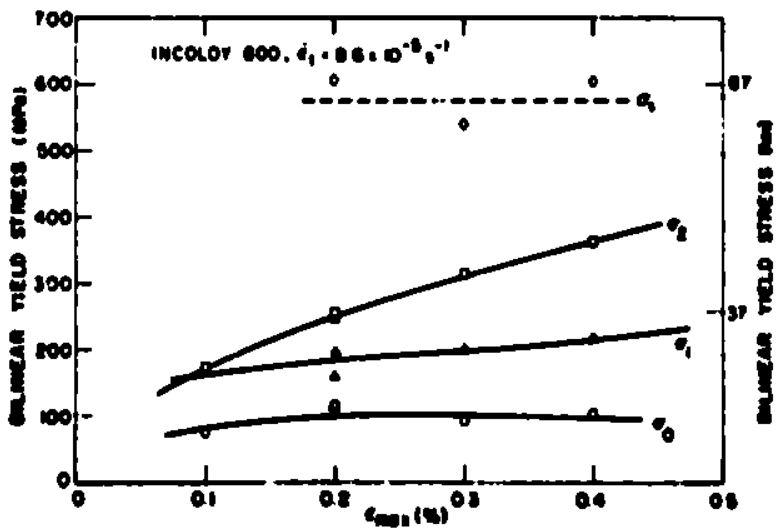

Flg. 14. Blinear Yleld Streas as a Function of emax at $638^{\circ} \mathrm{C}(1000 \%)$. ANL Neg. No. 308-77-283.

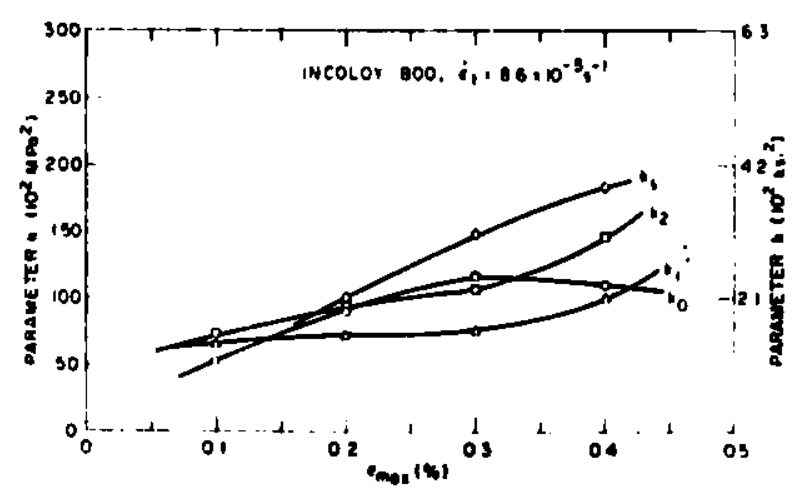

Fig. 11. Variation of Parameter $k$ with $\varepsilon_{\max }$ at Room Temperature. ANL Neg. No. 306-77-217 Rev. 1.

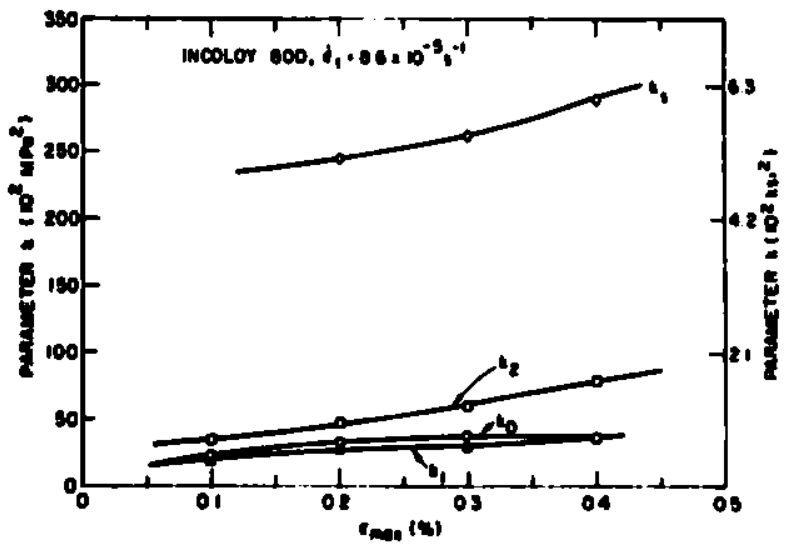

Fig. 13. Varlation of Parameter $k$ with $\operatorname{man}_{3 x}$ at $427^{\circ} \mathrm{C}\left(800^{\circ} \mathrm{F}\right)$. Neg. No. MSD-64001.

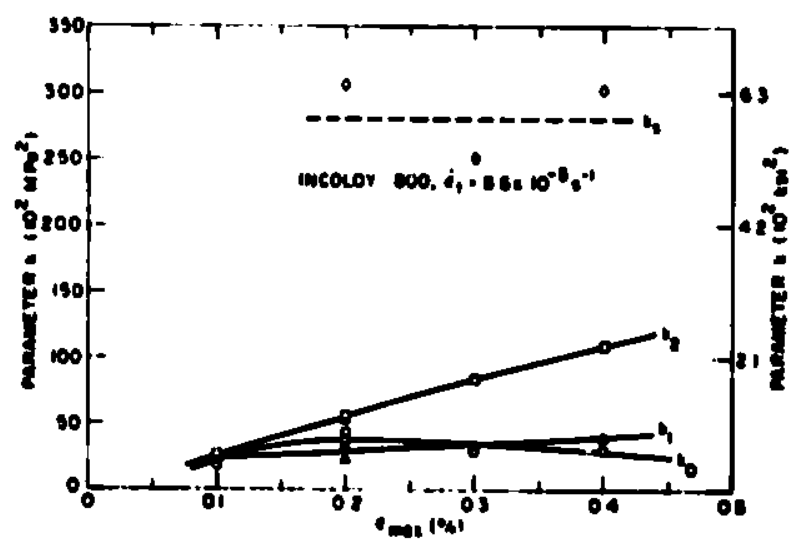

FIg. 15. Varlation of Parameter k with Gmix at 638'C (1000\%). ANL Neg. No, 308-77-227. 


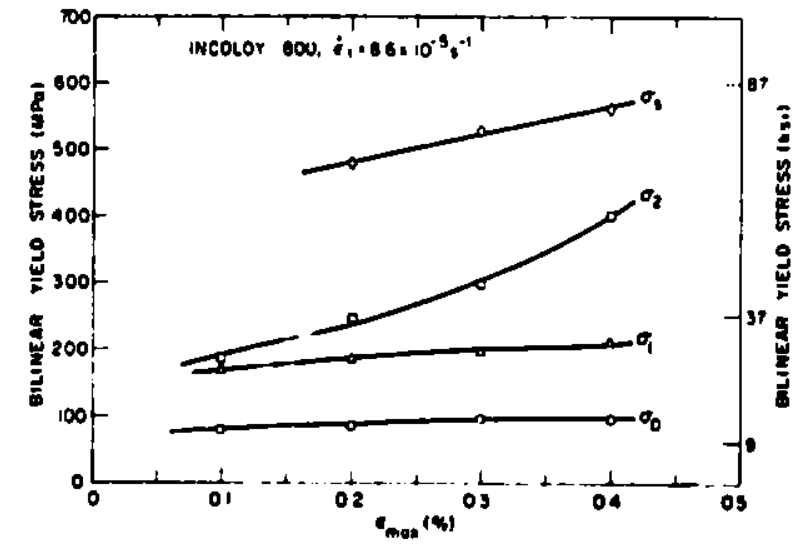

Flg. 16. Bilinear Yield Stress as a Function of $e_{\max }$ at $593^{\circ} \mathrm{C}\left(1100^{\circ} \mathrm{F}\right)$. ANL Neg. No, 306-77-229.

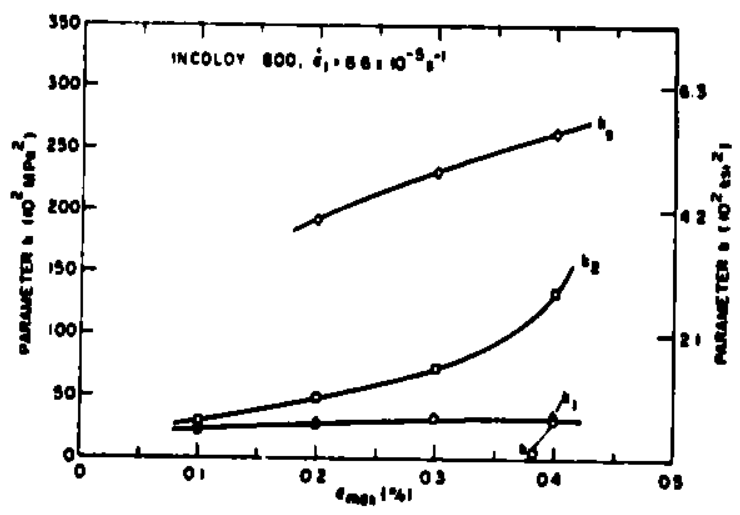

Fig. 17. Variation of Parameter $k$ with $\varepsilon_{\max }$ at $593^{\circ} \mathrm{C}\left(1100^{\circ} \mathrm{F}\right)$. Neg. No. MSD-64002.

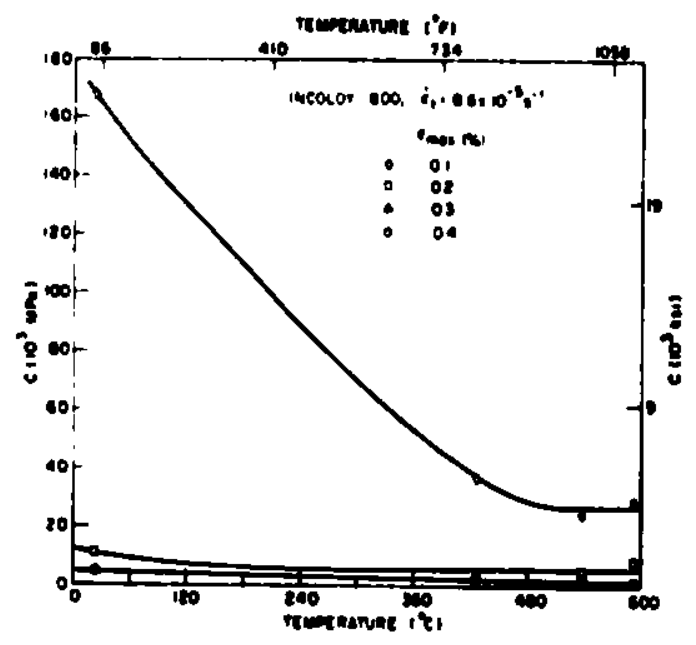

Fig. 18. Variation of $C$ with Temperature. INL. Neg. No. 306-77-225.

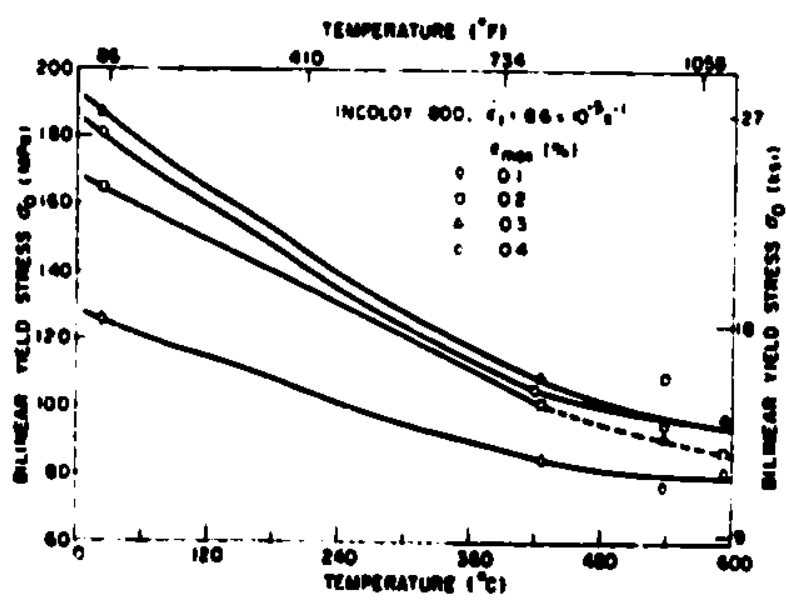

Fig. 20. Varlation of 00 with Temperature. ANL Neg. No. 306-77-218.

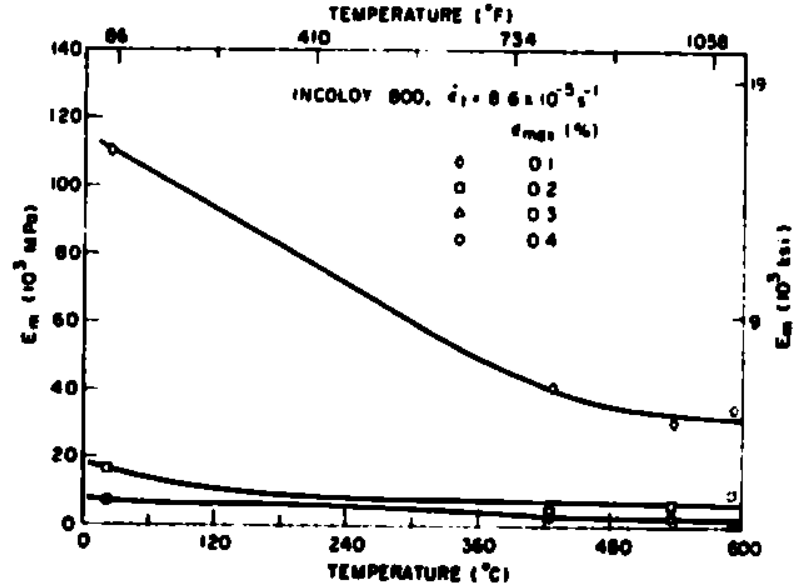

Fig. 19. Variation of $E_{m}$ with Temperature. ANL Neg. No. 306-77-235.

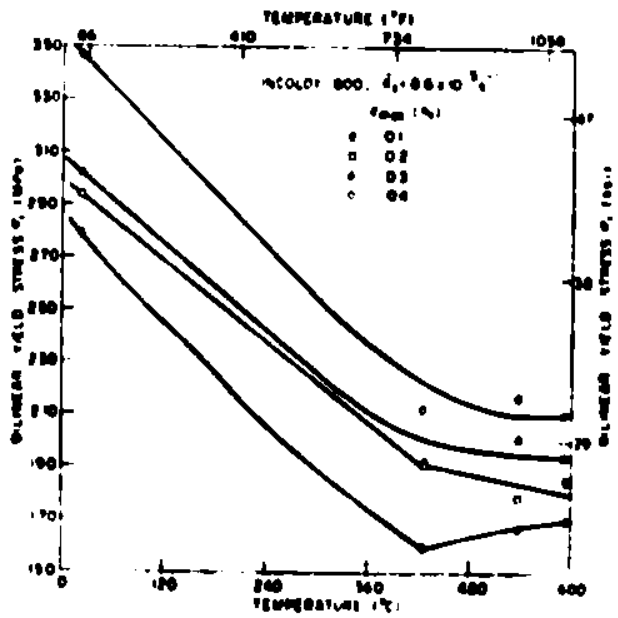

Fig. 21. Variation of $\sigma_{1}$ with Temperature. ANL Neg. No. 306-77-226. 


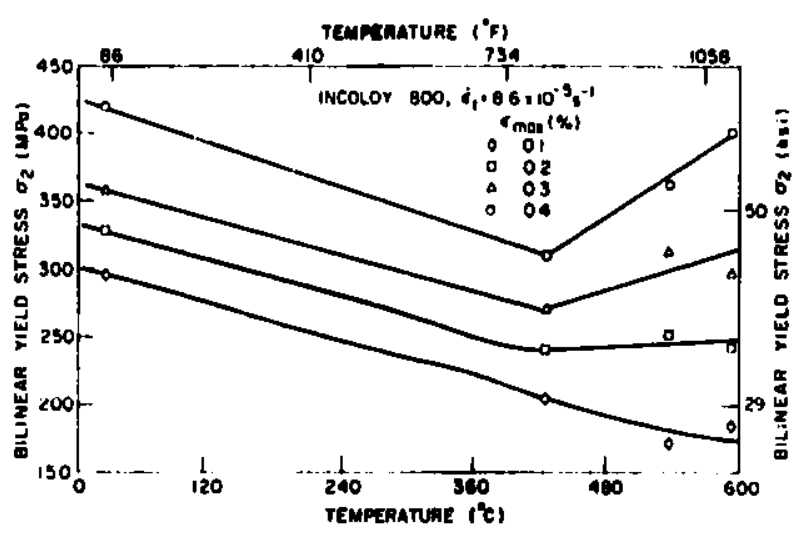

Fig. 22. Varlation of on with Temperature. ANL Neg. No. 306-77-219.

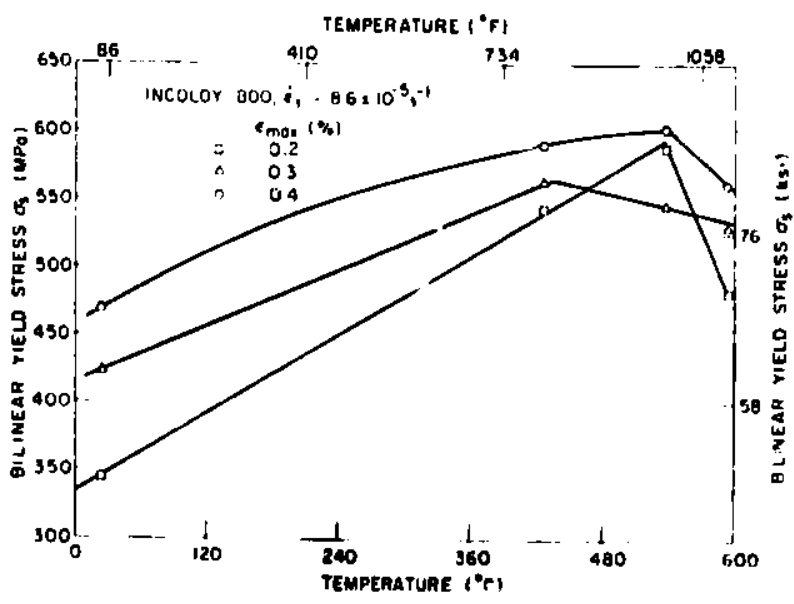

Fig. 23. Variation of $o_{s}$ witl Temperature. ANL. Neg. No. 30ki-77-220.

The precipitated phases in Incoloy 800 are usually titanium nitrides, titanium carbides, and chromium carbides. In addition to the above phases. a gamma-prime type of precipitate (face-centered-cubic structure $r i c h$ in nickel, aluminum, and titanium) may form upon long-time (over $100 \mathrm{~h}$ ) exposure to temperatures of $565-630^{\circ} \mathrm{C}$. The bilinear yield stress at saturation $\sigma_{\mathrm{s}}$ also shows anomalous behavior between 427 and $593^{\circ} \mathrm{C}$. These observations suggest that it is not very realistic to assume smooth variation of bilinear cyclic parameters with temperature in the region where experimental data are not available.

Finally, it is required to change the bilinear yield parameter from $k_{0}$ to $k$ in many design situations in which accurate representation of bilinear cyclic hardening behavior for the initial few cycles (c.g., first 10 cycles) may be important. Corum and Pugh have recommended* that such $k$ change, be made on the basis of accumulated plastic strain. Tables VI-XVII contain the bilinear yield stress, the parameter $k$, and accumulated plastic strain (assumed without regard to sign). Figures 24-27 are plots of bilinear yield

TABLE VI. Bilinear Yicld Stress, Parameter k, and Accumulated Plastic Strain for Incoloy 800 at Room Temperature: $\Delta e t=0.4 \%$ and Strain Rate $=8.6 \times 10^{-5} \mathrm{~g}^{-1}$

\begin{tabular}{cccc}
\hline $\begin{array}{c}\text { Cycle } \\
\text { Number }\end{array}$ & $\begin{array}{c}\text { Bilinear Yield Stress, } \\
\text { MPa (ksi) }\end{array}$ & $\begin{array}{c}\text { Parameter k, } \\
\left.\text { MPa }^{2}(\mathbf{k s i})^{2}\right)\end{array}$ & $\begin{array}{c}\text { Accumulated } \\
\text { Plastic Strain, } \\
\%\end{array}$ \\
\hline 1 & $293.86(42.62)$ & $7196(151.4)$ & 0.420 \\
2 & $306.22(44.41)$ & $7814(164.4)$ & 0.827 \\
3 & $312.78(45.36)$ & $8153(171.5)$ & 1.222 \\
4 & $315.03(45.69)$ & $8270(174.0)$ & 1.614 \\
5 & $318.87(46.25)$ & $8473(178.2)$ & 1.998 \\
6 & $321.09(46.57)$ & $8592(180.7)$ & 2.378 \\
7 & $322.84(46.82)$ & $8685(182.7)$ & 2.755 \\
8 & $324.87(47.12)$ & $8795(185.0)$ & 3.128 \\
9 & $326.46(47.35)$ & $8881(186.8)$ & 3.498 \\
10 & $327.73(47.53)$ & $8950(188.3)$ & 3.864 \\
\hline
\end{tabular}


TAB LE VII. Bilinear Yield Stress. Parameter $k$, and Accumulated Plastic Strain for Incoloy 800 at Room Temperature: $\Delta \varepsilon_{t}=0.6 \%$ and Strain Rate $=8.6 \times 10^{-5} \mathrm{~s}^{-1}$

\begin{tabular}{cccc}
\hline $\begin{array}{c}\text { Cycle } \\
\text { Number }\end{array}$ & $\begin{array}{c}\text { Bilinear Yield Strcss, } \\
\text { MPa (ksi) }\end{array}$ & $\begin{array}{c}\text { Parameter k. } \\
\mathrm{MPa}^{2}\left(\mathrm{ksi}^{2}\right)\end{array}$ & $\begin{array}{c}\text { Accumulated } \\
\text { Plastic Strain, } \\
\%\end{array}$ \\
\hline 1 & $303.91(44.08)$ & $7697(161.9)$ & 0.814 \\
2 & $319.66(46.36)$ & $8515(179.1)$ & 1.606 \\
3 & $331.75(48.12)$ & $9172(192.9)$ & 2.382 \\
4 & $339.65(49.26)$ & $9614(202.2)$ & 3.145 \\
5 & $342.55(49.68)$ & $9778(205.7)$ & 3.904 \\
6 & $347.40(50.39)$ & $10057(211.6)$ & 4.649 \\
7 & $349.98(50.76)$ & $10207(214.7)$ & 5.391 \\
8 & $352.50(51.13)$ & $10355(217.8)$ & 6.130 \\
9 & $354.68(51.44)$ & $10483(220.5)$ & 6.862 \\
10 & $357.49(51.85)$ & $10650(224.0)$ & 7.591 \\
\hline
\end{tabular}

TABLE VII. Bilinear Yield Stress, Parameter $k$, and Accumulated Plastic Strain for Incoloy 800 at Room Temperature: $\Delta c t=0.8 \%$ and Strain Rate $=8.6 \times 10^{-5} \mathrm{~s}^{-1}$

\begin{tabular}{cccc}
\hline $\begin{array}{c}\text { Cycle } \\
\text { Number }\end{array}$ & $\begin{array}{c}\text { Bilinear Yield Stres s, } \\
\mathrm{MPa}(\mathrm{ksi})\end{array}$ & $\begin{array}{c}\text { Parametcr k, } \\
\mathrm{MPa}^{2}\left(\mathrm{ksi}^{2}\right)\end{array}$ & $\begin{array}{c}\text { Accumulated } \\
\text { Plastic Strain, } \\
\%\end{array}$ \\
\hline 1 & $347.47(50.40)$ & $10061(211.6)$ & 1.242 \\
2 & $371.13(53.83)$ & $11478(241.4)$ & 2.452 \\
3 & $383.25(55.59)$ & $12240(257.5)$ & 3.642 \\
4 & $394.62(57.23)$ & $12977(273.0)$ & 4.817 \\
5 & $403.18(58.48)$ & $13546(285.0)$ & 5.98 \\
6 & $404.55(58.67)$ & $13638(286.9)$ & 7.134 \\
7 & $407.15(59.05)$ & $13814(290.6)$ & 8.280 \\
8 & $412.40(59.81)$ & $14173(298.1)$ & 9.418 \\
9 & $416.53(60.41)$ & $14458(304.1)$ & 10.551 \\
10 & $419.02(60.77)$ & $14631(307.8)$ & 11.679 \\
\hline
\end{tabular}

TABLE IX. Bilinear Yield Stres8, Parameter K, and Accumulated Plastic Strain for Incoloy 800 at $427^{\circ} \mathrm{C}\left(800^{\prime \prime} \mathrm{F}^{\prime}\right.$. Det $=0.4 \%$ and Strain Rate $=8.6 \times 10^{-5} \cdots$

\begin{tabular}{cccc}
\hline $\begin{array}{c}\text { Cycle } \\
\text { Number }\end{array}$ & $\begin{array}{c}\text { Bilinear Yield Stres8, } \\
\text { MPa (kBi) }\end{array}$ & $\begin{array}{c}\text { Parameter k, } \\
\mathrm{MPa}^{2}\left(\mathrm{kBi}^{2}\right)\end{array}$ & $\begin{array}{c}\text { sccumulated } \\
\text { Plastic Strain, } \\
\%\end{array}$ \\
\hline 1 & $190.96(27.7)$ & $3039(63.9)$ & 0.501 \\
2 & $202.62(29.39)$ & $3421(72.0)$ & 1.000 \\
3 & $210.19(30.49)$ & $3682(77.4)$ & 1.470 \\
4 & $215.06(31.19)$ & $3854(81.1)$ & 1.932 \\
5 & $223.48(32.41)$ & $4162(87.5)$ & 2.38 \\
6 & $225.56(32.71)$ & $4240(89.4)$ & 2.824 \\
7 & $229.10(33.22)$ & $4374(92.0)$ & 3.260 \\
8 & $233.03(33.80)$ & $4525(95.7)$ & 3.691 \\
9 & $235.95(34.22)$ & $4639(97.0)$ & 4.118 \\
10 & $239.59(34.75)$ & $4784(100.6)$ & 4.539 \\
\hline
\end{tabular}


TABLE X. Bilincar Yield Stress, Parameter $k$, and Accumulated Plastic Strain for Incoloy 800 at $427^{\circ} \mathrm{C}\left(800^{\circ} \mathrm{E}\right)$ : $\quad$ ct $=0.6 \%$ and Strain Rate $=8.6 \times 10^{-5} \mathrm{~s}^{-1}$

\begin{tabular}{cccc}
\hline $\begin{array}{c}\text { Cycle } \\
\text { Number }\end{array}$ & Bilinear Yield Stress, & Parameter k, & Accumulated \\
$\mathrm{MPa}^{2}\left(\mathrm{ksi}^{2}\right)$ & $\begin{array}{c}\text { Plastic Strain, } \\
\%\end{array}$ & \\
\hline 1 & $\mathrm{MPa}(\mathrm{ksi})$ & $3061(64.4)$ & 0.923 \\
2 & $191.66(27.80)$ & $3696(77.7)$ & 1.818 \\
3 & $210.59(30.54)$ & $4269(89.8)$ & 2.693 \\
4 & $226.34(32.83)$ & $4653(97.9)$ & 3.548 \\
5 & $236.30(34.27)$ & $4966(104.5)$ & 4.390 \\
6 & $244.11(35.41)$ & $5160(108.5)$ & 5.221 \\
7 & $248.83(36.09)$ & $5401(113.6)$ & 6.047 \\
8 & $254.58(36.92)$ & $5552(116.8)$ & 6.867 \\
9 & $258.12(37.44)$ & $5669(119.2)$ & 7.679 \\
10 & $260.81(37.83)$ & $6065(127.6)$ & 8.482 \\
\hline
\end{tabular}

TABLE XI. Bilinear Yield Stress, Parameter $k$, and Accumulated Plastic Strain for Incoloy 800 at $427^{\circ} \mathrm{C}\left(800^{\circ} \mathrm{F}\right)$ : $\Delta e t=0.8 \%$ and Strain Rate $=8.6 \times 10^{-5} \mathrm{~s}^{-1}$

\begin{tabular}{cccc}
\hline $\begin{array}{c}\text { Cycle } \\
\text { Number }\end{array}$ & $\begin{array}{c}\text { Bilinear Yiejd Stress, } \\
\text { MPa (ksi) }\end{array}$ & $\begin{array}{c}\text { Parameter k. } \\
M^{2}\left(\mathrm{ksi}^{2}\right)\end{array}$ & $\begin{array}{c}\text { Accumulated } \\
\text { Plastic Strain, } \\
\text { \% }\end{array}$ \\
\hline 1 & $212.43(30.81)$ & $3760(79.1)$ & 1.289 \\
2 & $243.50(35.32)$ & $4941(103.9)$ & 2.531 \\
3 & $261.12(37.87)$ & $5682(119.5)$ & 3.744 \\
4 & $271.95(39.44)$ & $6163(129.6)$ & 4.94 .4 \\
5 & $284.96(41.33)$ & $6767(142.3)$ & 6.120 \\
6 & $292.66(42.45)$ & $7137(150.1)$ & 7.288 \\
7 & $298.90(43.35)$ & $7445(156.6)$ & 8.443 \\
8 & $304.81(44.21)$ & $7743(162.9)$ & 9.587 \\
9 & $307.11(44.54)$ & $7859(165.3)$ & 10.72 \\
10 & $309.76(44.93)$ & $7996(168.2)$ & 11.85 \\
\hline
\end{tabular}

TABLE XU. Bilinear Yield Stress, Parameter $k$, and Accumulated Plastic Strain for Incoloy 800 at $538^{\circ} \mathrm{C}\left(1000^{\circ} \mathrm{F}\right): \Delta e_{t}=0.4 \%$ and Strain Rate $=8.6 \times 10^{-5} \mathrm{8}^{-1}$

\begin{tabular}{|c|c|c|c|}
\hline $\begin{array}{l}\text { Cycle } \\
\text { Number }\end{array}$ & $\begin{array}{c}\text { Bdlinear Yield Stress, } \\
\text { MPa (kst) }\end{array}$ & $\begin{array}{l}\text { Parameter } k \text {, } \\
\mathrm{Mra}^{2}\left(\mathrm{kai}^{2}\right)\end{array}$ & $\begin{array}{c}\text { Accumulated } \\
\text { Plastic Strain, } \\
\%\end{array}$ \\
\hline $\begin{array}{r}1 \\
2 \\
3 \\
4 \\
5 \\
6 \\
7 \\
8 \\
9 \\
10\end{array}$ & $\begin{array}{l}197.84(28.69) \\
211.60(30.69) \\
221.83(32.17) \\
231.99(33.65) \\
237.48(34.44) \\
240.95(34.95) \\
242.82(35.22) \\
247.70(35.93) \\
250.67(36.36) \\
253.85(36.82)\end{array}$ & $\begin{array}{l}3262(68.6) \\
3731(78.5) \\
4101(86.3) \\
4485(94.3) \\
4700(98.9) \\
4838(101.8) \\
4913(103.4) \\
5113(107.6) \\
5236(110.2) \\
5370(113.0)\end{array}$ & $\begin{array}{l}0.504 \\
0.989 \\
1.464 \\
1.924 \\
2.373 \\
2.815 \\
3.249 \\
3.676 \\
4.094 \\
4.509\end{array}$ \\
\hline
\end{tabular}


TAB LE XIII. Bilinear Yield Stress, Parameter $k$, and Accumulated Plastic Strain for Incoloy 800 at $538^{\circ} \mathrm{C}\left(1000^{\circ} \mathrm{F}\right): \Delta \mathrm{c}_{\mathrm{t}}=0.6 \%$ and Strain Rate $=8.6 \times 10^{-5},-1$

\begin{tabular}{cccc}
\hline $\begin{array}{c}\text { Cycle } \\
\text { Number }\end{array}$ & $\begin{array}{c}\text { Bilinear Yield Stress, } \\
\text { MPa (ksi) }\end{array}$ & $\begin{array}{c}\text { Parameter k, } \\
\mathrm{MPa}^{2}\left(\mathrm{ksi}^{2}\right)\end{array}$ & $\begin{array}{c}\text { Accumulated } \\
\text { Plastic Strain, } \\
\%\end{array}$ \\
\hline 1 & $201.12(29.17)$ & $3371(70.9)$ & 0.958 \\
2 & $229.77(33.32)$ & $4399(92.5)$ & 1.885 \\
3 & $249.99(36.26)$ & $5208(109.6)$ & 2.782 \\
4 & $270.01(39.16)$ & $6076(127.8)$ & 3.655 \\
5 & $280.57(40.69)$ & $6560(138.0)$ & 4.503 \\
6 & $289.04(41.92)$ & $6962(146.5)$ & 5.340 \\
7 & $298.89(43.35)$ & $7444(156.6)$ & 6.156 \\
8 & $302.50(43.87)$ & $7626(160.0)$ & 6.963 \\
9 & $304.17(44.12)$ & $7710(162.2)$ & 7.758 \\
10 & $313.48(45.47)$ & $8189(172.3)$ & 8.549 \\
\hline
\end{tabular}

TABLE XIV. Bilinear Yield Stress, Parameter k, and Accumulated Plastic Strain for Incoloy 800 at $538^{\circ}\left(:\left(1000^{\circ} \mathrm{F}\right): \Delta \mathrm{ct}=0.8 \%\right.$ and Strain Rate $=8.6 \times 10^{-5} \mathrm{~s}^{-1}$

\begin{tabular}{cccc}
\hline $\begin{array}{c}\text { Cycle } \\
\text { Number }\end{array}$ & $\begin{array}{c}\text { Bilinear Yield Stress, } \\
\text { MPa (ksi) }\end{array}$ & $\begin{array}{c}\text { Parameter k. } \\
\mathrm{MPa}^{2}\left(\mathrm{ksi}^{2}\right)\end{array}$ & $\begin{array}{c}\text { Accumulated } \\
\text { Plastic Strain. } \\
\%\end{array}$ \\
\hline 1 & $217.06(31.48)$ & $3926(82.6)$ & 1.303 \\
2 & $267.34(38.77)$ & $5956(125.3)$ & 2.545 \\
3 & $294.41(42.70)$ & $7223(151.9)$ & 3.749 \\
4 & $300.96(43.65)$ & $7548(158.8)$ & 4.927 \\
5 & $314.40(45.60)$ & $8237(173.3)$ & 6.082 \\
6 & $329.25(47.75)$ & $9034(190.0)$ & 7.216 \\
7 & $337.50(48.95)$ & $9492(199.7)$ & 8.330 \\
8 & $347.91(50.46)$ & $10087(212.2)$ & 9.431 \\
9 & $351.38(50.96)$ & $10289(216.4)$ & 10.53 \\
10 & $362.18(52.53)$ & $10931(229.9)$ & 11.613 \\
\hline
\end{tabular}

TABLE XV. Bilinear Yicld Stress. Parameler k, and Accumulated Plastic Strain for Incoloy 800 at $593 \mathrm{C}(1100 \mathrm{~F}) . \Delta \mathrm{ct}=0.4 \%$ and Strain Rate $=8.6 \times 10^{-4} \mathrm{~g}^{-1}$

\begin{tabular}{|c|c|c|c|}
\hline $\begin{array}{l}\text { Cycle } \\
\text { Number }\end{array}$ & $\begin{array}{c}\text { Bilincar Yield Stress, } \\
M P_{\mathrm{a}} \text { (ksi) }\end{array}$ & $\begin{array}{c}\text { Parameter k. } \\
\operatorname{MPa}^{2}\left(k i^{2}\right)\end{array}$ & $\begin{array}{c}\text { Accunulated } \\
\text { Plastic Strain. } \\
\%\end{array}$ \\
\hline 1 & $185.06(26.84)$ & $2854(60.0)$ & 0.526 \\
\hline 2 & $197.84(28.69)$ & $3262(68.6)$ & 1.036 \\
\hline 3 & $206.86(30.00)$ & $3566(75.0)$ & 1.528 \\
\hline 4 & $213.33(30.94)$ & $3792(79.8)$ & 2.009 \\
\hline 5 & $222.01(32.20)$ & $4108(86.2)$ & 2.478 \\
\hline 6 & $229.30(33.26)$ & $4382(92.2)$ & 2.933 \\
\hline 7 & $232.50(33.72)$ & $4505(94.8)$ & 3.386 \\
\hline 8 & $234.84(34.06)$ & $4596(96.7)$ & 3.833 \\
\hline 9 & $238.0(34.52)$ & $4720(99.3)$ & 4.274 \\
\hline 10 & $243.09(35.26)$ & $4924(103.6)$ & 4.708 \\
\hline
\end{tabular}


TABLE XVI. Bilinear Yield Stress, Parameter $k$, and Accumulated

Plastic Strain for Incoloy 800 at $593^{\circ} \mathrm{C}\left(1100^{\circ} \mathrm{F}\right): \Delta \varepsilon_{t}=0.6 \%$ and Strain Rate $=8.6 \times 10^{-5} \mathrm{~s}^{-1}$

\begin{tabular}{cccc}
\hline $\begin{array}{c}\text { Cycle } \\
\text { Number }\end{array}$ & $\begin{array}{c}\text { Bilinear Yield Stress, } \\
\mathrm{MPa}(\mathrm{kgi})\end{array}$ & $\begin{array}{c}\text { Parameter k, } \\
\mathrm{MPa}^{2}\left(\mathrm{ksi}^{2}\right)\end{array}$ & $\begin{array}{c}\text { Accumulated } \\
\text { Plastic Strain. } \\
\%\end{array}$ \\
\hline 1 & $195.28(28.32)$ & $3178(66.8)$ & 0.914 \\
2 & $223.22(32.38)$ & $4152(87.3)$ & 1.792 \\
3 & $240.63(34.90)$ & $4825(101.5)$ & 2.640 \\
4 & $253.71(36.80)$ & $5364(112.8)$ & 3.462 \\
5 & $264.25(38.33)$ & $5819(122.4)$ & 4.265 \\
6 & $273.63(39.69)$ & $6240(131.3)$ & 5.054 \\
7 & $278.59(40.41)$ & $6468(136.1)$ & 5.831 \\
8 & $282.52(40.98)$ & $6651(139.9)$ & 6.597 \\
9 & $288.73(41.88)$ & $6947(146.1)$ & 7.350 \\
10 & $295.80(42.903)$ & $7292(153.4)$ & 8.096 \\
\hline
\end{tabular}

TABLE XVII. Bilinear Yield Stress, Parameter k, and Accumulated Plastic Strain for Incoloy 800 at $593 \mathrm{C}\left(1100^{\circ} \mathrm{F}\right): \Delta \mathrm{e}_{\mathrm{t}}=0.8 \%$ and Strain Rate $=8.6 \times 10^{-5} \mathrm{~s}^{-1}$

\begin{tabular}{cccc}
\hline $\begin{array}{c}\text { Cycle } \\
\text { Number }\end{array}$ & $\begin{array}{c}\text { Bilinear Yield Stress, } \\
\text { MPa (ksi) }\end{array}$ & $\begin{array}{c}\text { Parameter k. } \\
\mathrm{MPa}^{2}\left(\mathrm{ksi}^{2}\right)\end{array}$ & $\begin{array}{c}\text { Accumulated } \\
\text { Plastic Strain. } \\
\%\end{array}$ \\
\hline 1 & $210.26(30.5)$ & $3684(77.5)$ & 1.305 \\
2 & $256.27(37.17)$ & $5473(115.1)$ & 2.561 \\
3 & $289.10(41.93)$ & $6965(146.5)$ & 3.775 \\
4 & $313.57(45.48)$ & $8194(172.4)$ & 4.958 \\
5 & $333.51(48.37)$ & $9269(195.0)$ & 6.116 \\
6 & $350.14(50.78)$ & $10216(214.9)$ & 7.256 \\
7 & $367.49(53.30)$ & $11254(236.7)$ & 8.374 \\
8 & $376.37(54.59)$ & $11804(248.3)$ & 9.478 \\
9 & $390.74(56.67)$ & $12723(267.6)$ & 10.566 \\
10 & $401.39(58.22)$ & $13426(282.4)$ & 11.641 \\
\hline
\end{tabular}

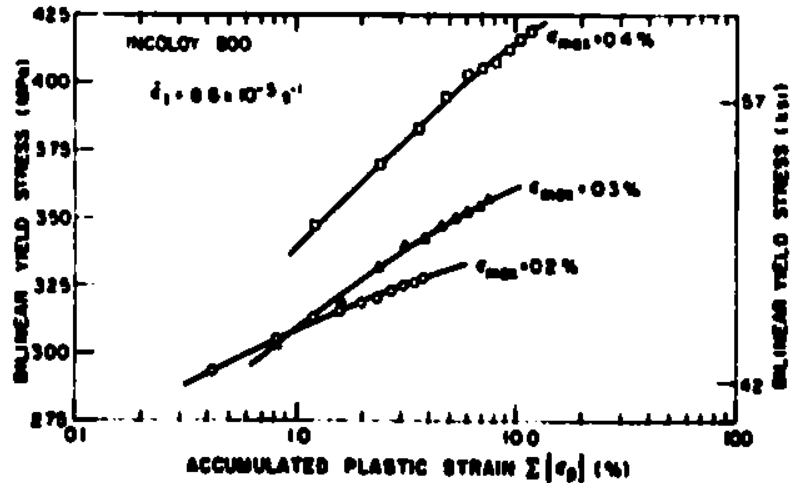

Fig. 24

Vartation of Blincar Yleld Strcas Range with Accumulated Plastic Straln at Room Temperature. ANL Neg. No. 306-77-224.

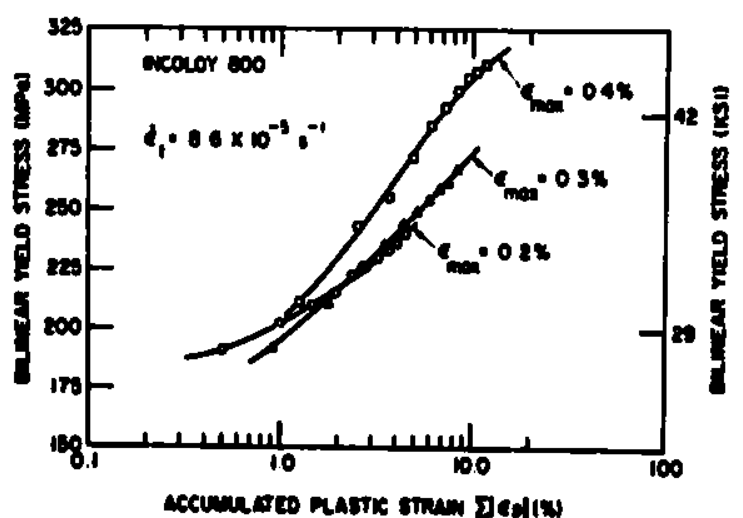

Fig. 25

Varlation of Bllinear Yicld Strese Range with) Acrumulated Plastic Strain at 427"(: $\left(800^{\circ} \mathrm{F}\right)$. Neg. No. MST2-64009. 


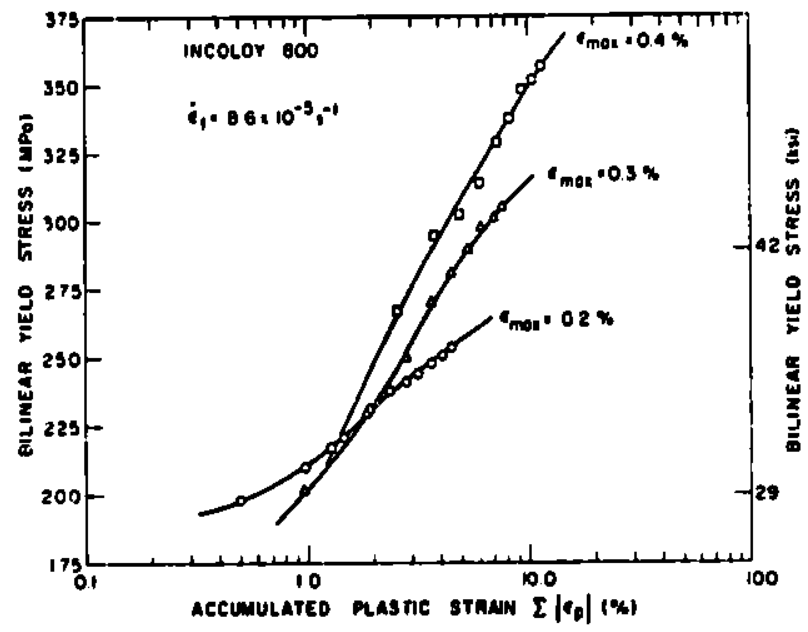

Fig. 26

Variation of Bilinear Yield Stress Range with Accumulated Plastic Straln at $538^{\circ} \mathrm{C}\left(1000^{\circ} \mathrm{F}\right)$. ANL Neg. No. 306-77-236.

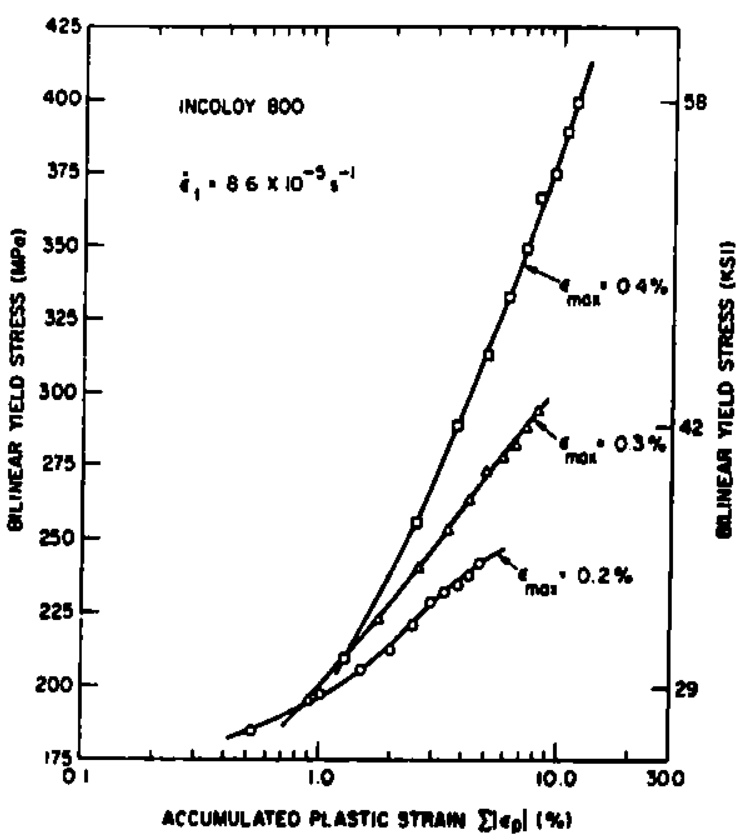

Fig. 27

Variation of Bllinear Yield Stress Range with Accumulated Plastic Strain at $593^{\circ} \mathrm{C}\left(1100^{\circ} \mathrm{F}\right)$. ANL Neg. No. 306-77-234.

stress versus accumulated plastic strain for the three strains. The symbols on Figs. 24-27 represent the bilinear yield stress for each individual cycle up to ten cycles.

The bilinear cyclic hardening curves can be empirically described by using a modified Voce-type equation. ${ }^{7}$ The present study shows that good correlation is obtained by using the bilinear parameter $k$ instead of bilinear yield stress. The experimental data obtained in the range of $427-593^{\circ} \mathrm{C}$ were considered and fit to the following modified Voce-type equation:

$$
\frac{k_{8 v}-k}{k_{B V}-k_{0 V}}=\exp \left(-k_{e} \sum\left|e_{p}\right|\right)
$$

where $\sum\left|e_{p}\right|$ is the accumulated plastic strain, and $k_{8 v}, k_{0 v}$, and $k_{c}$ are empirical parameters, which depend on material, temperature, emax, and otrain rate.

The parameter $8 \mathrm{k}_{\mathrm{BV}}, \mathrm{k}_{\mathrm{OV}}$, and $\mathrm{k}_{\mathrm{f}}$ in $\mathrm{Eq} .9$ were determined from a computer fit of the data by means of a variable-metric minimization program and are listed in Table XVIII. These parameters describe the bilinear hardening behavior satisfactorily, as can be seen from Figs. 28-30, where the symbols represent the experimental points. Furthermore, the constants $\mathrm{k}_{\mathrm{BV}}$ and $k_{0 v}$ normalized by the shear modulus $\mu$ and $k_{c}$ appear to be interdependent in a manner analogous to that established for the description of monotonic stress-atrain curves by the Voce equation. For example, as shown in 
Figs. 31 and $32, k_{s v}$ and $k_{0 v}$ normalized by the temperature-dependent shear modulus and $k_{\epsilon}$ are interrelated by the relations

$$
\frac{k_{B v}}{\mu^{2}}=\alpha\left(k_{\varepsilon}\right)^{\beta}
$$

and

$$
\left(k_{s v}-k_{0 v}\right) / \mu^{2}=a\left(\frac{k_{g v}}{\mu^{2}}\right)^{b} .
$$

The values of $\alpha, \beta, a$, and $b$ in Eqs. 10 and 11 are $3.79 \times 10^{-5},-0.905,112.6$, and 1.39 , respectively.

Thus, changing $k$ from $k_{0}$ during continuous fixed-strain-range cycling correlates well with the accumulated plastic strain by using a modified Vocetype equation, and the correlation is expected to be useful in the analysis of structural components.

TABLE XVIIl. Empirical Parameters of Modified

\begin{tabular}{|c|c|c|c|}
\hline $\max _{\%}$ & $\begin{array}{c}\mathrm{kgv}_{\mathrm{Bv}} \cdot 10^{2} \\
\mathrm{MPa}^{2}\end{array}$ & $\begin{array}{c}\mathrm{k}_{\mathrm{ov}} \cdot 10^{2} \\
\mathrm{MPa}^{2}\end{array}$ & $k_{e}$ \\
\hline \multicolumn{4}{|c|}{$\underline{427^{\circ} \mathrm{C}}$} \\
\hline $\begin{array}{l}0.2 \\
0.3 \\
0.4\end{array}$ & $\begin{array}{l}54.82 \\
65.67 \\
86.17\end{array}$ & $\begin{array}{l}26.76 \\
23.11 \\
24.11\end{array}$ & $\begin{array}{l}29.54 \\
21.89 \\
19.72\end{array}$ \\
\hline \multicolumn{4}{|c|}{$\underline{538^{\circ} \mathrm{C}}$} \\
\hline $\begin{array}{l}0.2 \\
0.3 \\
0.4\end{array}$ & $\begin{array}{r}57.35 \\
91.10 \\
122.52\end{array}$ & $\begin{array}{l}26.42 \\
19.25 \\
23.64\end{array}$ & $\begin{array}{l}44.47 \\
22.81 \\
15.88\end{array}$ \\
\hline \multicolumn{4}{|c|}{$593^{\circ} \mathrm{C}$} \\
\hline $\begin{array}{l}0.2 \\
0.3 \\
0.4\end{array}$ & $\begin{array}{r}57.94 \\
81.69 \\
198.50\end{array}$ & $\begin{array}{l}23.81 \\
21.10 \\
18.04\end{array}$ & $\begin{array}{r}28.21 \\
22.22 \\
8.76\end{array}$ \\
\hline
\end{tabular}
Voce-type Equations for Incoloy 800

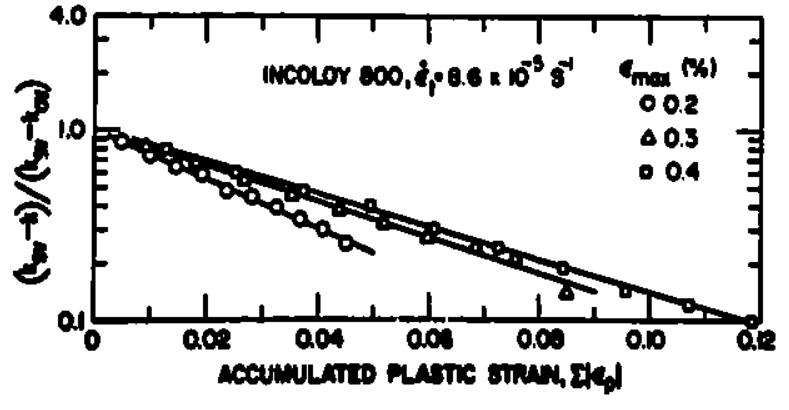

FIg. 28

Eit of Bilincar Cyclic Hardening Parameten to Modifled Voce-type Equation at $427^{\circ} \mathrm{C}\left(800^{\circ} \mathrm{F}\right)$. ANL Neg. No. 306-77-240 Rev. 1. 


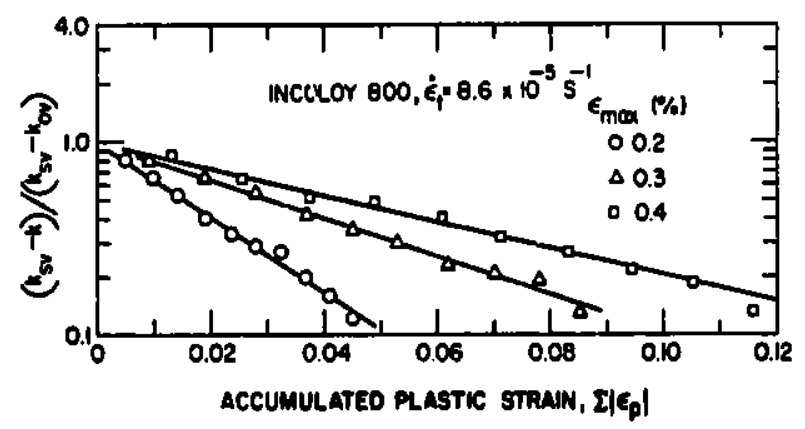

Fig. 29. Fit of Bilinear Cyclic Hardening Parameters to Modified Voce-type Equation at $538^{\circ} \mathrm{C}$ (1000\%). ANL Neg. No. 306-77-242.

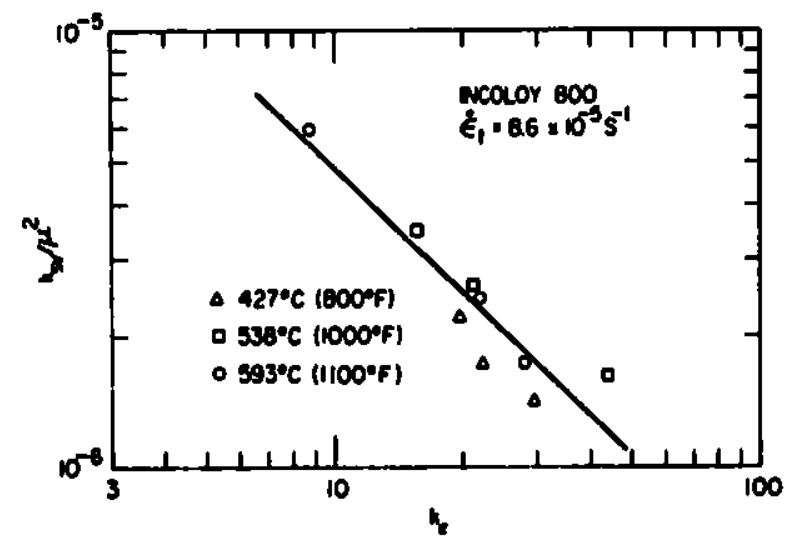

Fig. 31. Dependence of Modified Voce Constant ksv on ke. ANL Neg. No. 306-77-244.

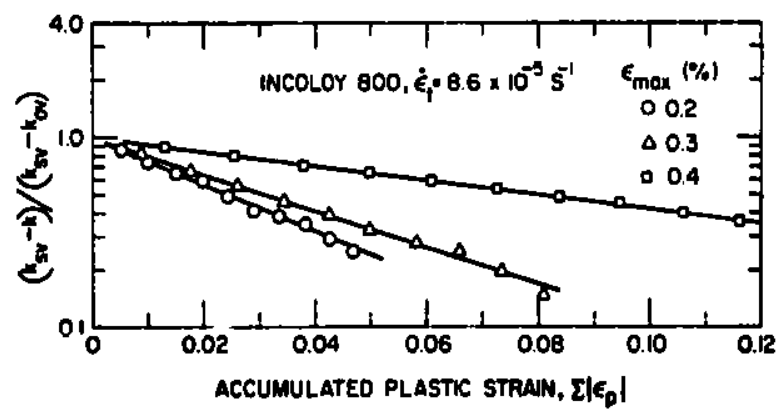

Fig. 30. Fit of Bilinear Cyclic Hardening Parameters to Modified Voce-type Equation at $593^{\circ} \mathrm{C}$ (1100 F). ANL Neg. No. 306-77-239 Rev. 1.

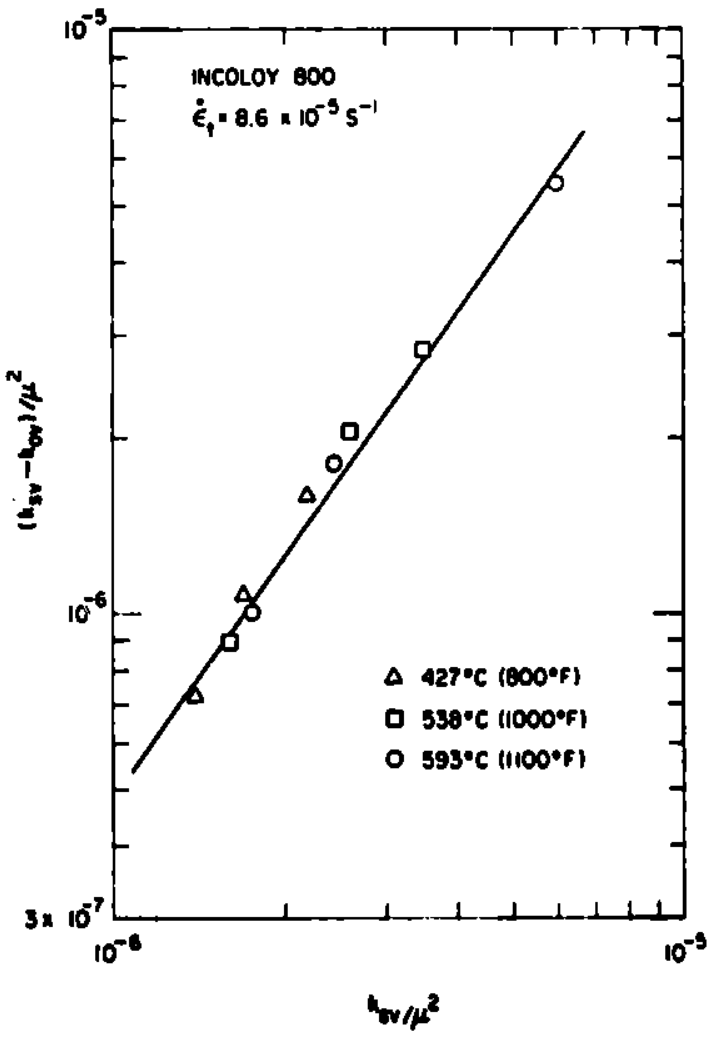

Fig. 32. Interdependence of Modlfied Voce Constants ksv and kov. ANL Neg. No. 306-77-243. 


\section{ACKNOW LEDGMENTS}

I wish to acknowledge the assistance of W. F. Burke, C. F. Peterson,

J. C. Tezak, and M. D. Gorman in conducting fatigue tests.

\section{REFERENCES}

1. J. E. Hilliard, Estimation of Grain Size by the Intercept Method, Met. Prog. 4, 99 (1964).

2. J. M. Corum, W. L. Greenstreet, K. C. L1n, C. E. Pugh, and R. W. Swindeman, Interim Guidelines for Detailed Inelastic Analysis of High-temperature Reactor Systems Component8, Oak Ridge National Laboratory, ORNL-5014 (Dec 1974).

3. RDT Standard 9-5T (Sept 1974).

4. International Nickel Company, Technical Bulletin T-40 (1973).

5. C. F. Cheng and C. Y. Cheng, "Bilinear Representations of Stress-Strain Behavior of Types 304 and 316 Stainless Steel Cyclically Deformed at 800-1200' F," in Proc. 2nd Int. Conf. on Structural Mechanics in Reactor Technology, Berlin, Germany, Vol. V(M), pp. 1-11 (Sept 1973).

6. C. F. Cheng and C. Y. Cheng, Bilinear Representations of the Cyclic StressStrain Behavior of Types 304 and 316 Stainless Steel from 800-1200' F, Argonne National Laboratory, ANL-8002 (Feb 1974).

7. E. Voce, The Relationship Between Stress and Strain for Homogeneous Deformation, J. Inst. Met. 74, 537 (1942).

8. 0. K. Chopra and K. Natesan, Representation of Elevated-temperature Tensile Behavior of Type 304 Stainlese Steel in a Sodilon Environment, J. Eng. Mater. Technol. (Trans ASME) 99(9), 366 (1977). 